\title{
Türkiye'de S/sağır ve İşitme Engelli Çocukların Televizyon Programlarına Engelsiz Erişiminde İsaret Dili Çevirisi Üzerine Bir Araştırma ${ }^{1}$
}

\author{
Accessibilty to Television Programs for the D/Deaf and Hard of Hearing Child \\ Audience in Turkey: A research on Sign Language Interpreting
}

Araştırma/Research

\section{A. Zeynep ORAL}

Doç. Dr., Hacettepe Üniversitesi, Edebiyat Fakültesi, Mütercim ve Tercümanlık Bölümü, zen@hacettepe.edu.tr, ORCID ID: orcid.org/0000-0001-6378-5464

\section{ÖZET}

Engelsiz dünya ve toplum bilinciyle artık engellilerin yaşama her alanda dahil edilmesini amaçlayan uluslararası ve ulusal düzenlemeler, yalnızca fiziki koşulların iyileştirilmesi ve elverişli hale getirilmesinin de ötesine geçerek bilgi, eğlence, haber vb. içeriklere de erişim sürecini kapsamaktadır. Teknolojik gelişmelerle haberleşme ve iletişim kaynaklarının giderek çeşitlendiği günümüz koşullarında erişim hayatın her alanında hem gerekli hem de kaçınılmaz bir ihtiyaç haline gelmiştir. Bu bağlamda toplumun yerel-alt kültürünün önemli bir parçası olan $\mathrm{S} /$ sağır ve işitme engellilerin ihtiyaçları göz önünde bulundurularak, akademi, devlet kurumları ve ilgili STK'ların eşgüdümüyle çevirinin bir alt alanı olan görsel işitsel çeviri ve "engelsiz erişim" alanında gözle görülür somut adımlar atılmıştır. Bu döngüyle Türkiye'de S/sağır ve işitme engellilere yönelik projeler giderek artarak, çeşitli alıcı gruplarına göre erişim konusunda saptanan eksiklikleri, işaret dili çevirmenlerinin karşılaştıkları zorlukları, çeviri süreçlerini ve türlerini ele alarak sistematik yapılar ortaya koymayı hedeflemektedir. Söz konusu gruplara yönelik yenilikçi girişimler arasında $\mathrm{S} /$ sağır ve işitme engelli çocuklara odaklanan projeler bulunmaktadır. Aldıkları eğitimin kalitesi ve kültürel farklılıkları nedeniyle işiten ve konuşan çocuklara oranla daha zorlu koşullarda yetişen bu çocukların dil edinimi, sosyalleşme, bilinç

\footnotetext{
${ }^{1}$ Bu çalışma, Sesli Betimleme Derneği (SEBEDER) tarafından 25 Ağustos-09 Ekim 2020 tarihleri arasında yürütülen ve tamamlanan "Sağır, İşitme Engelli ve Görme Engelli Çocukların Televizyon Programlarına Engelsiz Erişimi Projesi" çıktılarına dayanarak hazırlanmıştır.
} 
gelişimi için önemli ve tamamlayıcı olan projelerden bir tanesi de Sesli Betimleme Derneği (SEBEDER) tarafından 25 Ağustos-09 Ekim 2020 tarihleri arasında yürütülen ve tamamlanan 'Sağır, İşitme Engelli ve Görme Engelli Çocukların Televizyon Programlarına Engelsiz Erişimi Projesi'dir (bkz. http://sebeder.org/Projelerimiz-17.html). Bu çalışma söz konusu projenin işaret dili çevirisi bileşeninden elde edilen çıktılardan hareketle hazırlanmıştır. Proje kapsamında tamamlanan, çeviri teknikleri, yaklaşımları, zorluklarına çeşitli öneriler ve çözüm yolları sunan çevirmen kılavuzunun bir bölümü bu çalışmanın odağını oluşturmaktadır. Söz konusu kılavuz çocuk programlarında işaret dili çevrisi uygulamalarını düzenlemek ve kalite yönetimini sağlamak amacıyla hazırlanmıştır. Hem çevirmen hem de editörler için yol gösterici olan proje çıktısından hareketle, elde edilen verilerin belli bir sistem çerçevesinde sürekliliğinin ve iyileştirilmesinin sağlanması için medya sağlayıcıların S/sağır ve işitme engelli çocuklara yönelik görsel-işitsel ürünlere yönelik tercih çalışmaları yapmalarının önemi vurgulanmıştır.

Anahtar Sözcükler: işaret dili çevirisi, S/sağır ve işitme engelli çocuklar, çocuklar için engelsiz erişim, görsel-işitsel çeviri

\begin{abstract}
International and national regulations aiming the integration of the disabled persons in every field of life through recognizing their rights and creating a better understanding of their needs and appreciation of their capabilities not only includes creating a physically barrier-free world but also includes providing accessible audio-visual content. Currently, communication and communication resources are increasingly diversified due to technological developments. Thus accessibility has become both a necessary and an inevitable need in all areas of life. In this context, considering the needs of the D/deaf and Hard of Hearing people necessary steps have been taken in the field of Audio-Visual Translation and "accesibility" with the coordination of academia, government institutions and relevant NGOs. As a result, projects for the D/deaf and Hard of Hearing in Turkey have gradually increased. These projects are also diversified and address the deficiencies in audio-visual accessibility, the difficulties faced by sign language interpreters, interpreting processes and types. "Project for Accessibility to Television Programs for Blind, D/Deaf and Hard of Hearing Children", completed by the the Audio Description Association (SEBEDER) in August 25-October 9, 2020, is one of these innovative initiatives for D/deaf and Hard of Hearing people. This project can be accepted as one of the important projects for the language acquisition, socialization and awareness development of the disabled children, who grow up in more difficult conditions than the children who hear and speak. This study has been prepared based on the findings obtained from the sign language interpreting module of the project mentioned above, and it focuses on the translator guideline which gives information about approaches, methods, and practices concerning sign language interpreting process for D/deaf and Hard of Hearing child audience. The guideline also suggests recommendations and solutions for problems encountered by sign language interpreters, and it has been prepared in order to regulate sign language interpreting practices in children's programs and to ensure quality management. Based on the project output, the importance of the practices appreciated by media providers within the field of audio-visual products for D/deaf and Hard of Hearing for child audience is emhasized in order to ensure the continuity and improvement of the data obtained in light of the project carried out.
\end{abstract}

Keywords: sign language interpreting, D/Deaf and Hard-of-Hearing children, media accesibility for D/deaf and hard-of-hearing children 


\section{Giriş}

1989 yılında kabul edilen BM "Çocuk Hakları Sözleşmesi (ÇHS)" engellilere açıkça yer veren tek sözleşme olma niteliğini taşımaktadır. Bu sözleşmenin 23. maddesi tamamen engelli çocukları kapsamaktadır. Bu maddenin birinci fıkrasında, "Taraf Devletler zihinsel ya da bedensel özürlü çocukların saygınlıklarını güvence altına almayı, özgüvenlerini geliştirmeyi ve toplumsal yaşama etkin biçimde katılmalarını sağlar", ikinci fıkrasında, "özürlü çocuğun eğitimi, mesleki eğitimi, tıbbi bakım ve rehabilitasyon hizmetleri, bir işte çalışabilecek duruma getirme hazırlık programları ve dinlenme/eğlenme olanakları gibi özel bakımdan yararlanma hakkını kabul eder" ve üçüncü fıkrasında ise "söz konusu yardımın "olanaklar ölçüsünde ücretsiz" sağlayacaklarını taahhüt eder" ibareleri yer almaktadır (http:// www.unicef. org/ turkey/ crc/cr23d.html). Engelsiz dünya ve toplum bilinciyle artık engellilerin yaşama her alanda dahil edilmesini amaçlayan uluslararası ve ulusal düzenlemeler bilgi, eğlence, haber vb. içeriklere de erişim sürecini kapsamaktadır. Bu bağlamda $S /$ sağır ve işitme engelli çocukların eğlence, bilgi gibi içeriklere duyan konuşan çocuklarla eşerişimini sağlamak devlet kurumlarının olduğu kadar akademinin de sorumluluğu altındadır. Bu çerçevede son yıllarda engellilere yönelik çalışmalar devlet kurumları, ilgili dernek, STK'lar ve akademinin eşgüdümüyle farklı açılımlara yönelmiştir. Dünyadaki toplumsal, siyasal ve kültürel gerçeklere paralel olarak biçimlenen çeviri olgusu teknolojinin de gelişimiyle yenilikçi açıımlara doğru evrilmektedir. Bu olgudan hareketle görsel-işitsel çeviri üniversitelerin çeviribilim bölümlerinin lisans, yüksek lisans ve doktora programlarında yer almaya başlamıştır. Görsel işitsel çeviri şemsiyesi altında kör ve görme engelliler için sesli betimleme, $S$ /sağır ve işitme engelliler için ise işaret dili çevirisi, ayrıntılı alt yazı çevirisi gibi engelsiz erişim türleri akademik çerçevede ele alınmaya başlanmışır. İlgili engelli grupların da katkı sağlayarak dahil olduğu uygulamaya yönelik araştırma ve projeler alana katkı sağlamaya devam etmektedir (Görsel-işitsel Çeviri ve engelsiz erişim için bkz. Okyayuz, 2019a). Engelsiz erişim için çeviri türlerinin yaygınlaşmasının ardından zaman içinde engelli alt grupları hedef alan araştırmalar ve projeler yapılmaya başlanmıştır. $S /$ sağır ve işitme engellilere yönelik engelsiz erişim çeviri türlerinden biri olan altyazı çevirisi (Türkiye'deki adıyla ayrıntılı altyazı çevirisi yazı çevirisi) hem uygulama, hem de kuramsal açıdan farklı çalışmalar ışığında irdelenmiştir (ayrıntılı altyazı çevirisi için bkz. Okyayuz, 2019b). Bu bağlamda Ankara merkezli bir STK olan ve engelsiz erişim için görsel-işitsel ürünlerin çevirilerinde oldukça aktif rol oynayan SEBEDER'le (Sesli Betimleme Derneği) çeşitli projeler yürütülmüştür (bkz. SEBEDER projelerimiz). Engelli alt grupları arasında özellikle S/sağır ve işitme engelli çocuk alıcıların görsel-işitsel ürünlere erişiminde işaret dili çevirisi ve ayrıntılı altyazı çevirisi konusunda akademisyen, Sağır editörler ve işaret dili çevirmenlerinin eşgüdümüyle alana katkı sağlayan önemli projelerden biri de yine SEBEDER tarafından yürütülen, 2020 Ağustos ayında başlayıp Ekim ayında tamamlanan "Sağır, İsitme Engelli ve Görme Engelli Çocukların Televizyon Programlarına Engelsiz Erişimi" başlıklı projesidir. Projenin amacı Sağır kültürde büyüyen ve Türk Iş̧aret Dilini (TiD'i) ana dili olarak kullanan, işitme engelli olup ayrıntılı altyazı ile programlara erişimi 
olan çocuklarla görme engelli çocukların TRT Çocuk programlarına duydukları ilgiyi arttırmak, söz konusu alıııların programları izleme zevkini perçinlemek, yayınlara erişimle gelişen "yaşam ve toplumsallaşma" becerisini geliştirmek ve diğer çocuklar ile aynı haklara sahip olarak, yaşıtlarıyla eşit edinimlerini ve erişimlerini sağlamaktır (bkz. SEBEDER http://sebeder.org/Projelerimiz-17.html). Sancaktaroğlu Bozkurt ve Okyayuz (2021) Türkiye'de Sağır ve İşitme Engelli Çocuklar için Ayrıntılı Altyazı Çevirisi Hakkında Bir Araştırma: Uygulamada Sadeleştirme başlıklı makalelerinde söz konusu proje çıktısından hareketle uygulamada hem teknik hem de alıcı kitle itibariyle zorlu ve uzmanlık gerektiren ayrıntılı altyazı çevirisinde proje sürecinde örnekler ve geliştirilen sadeleştirme teknikleri açısından çevirmenlere rehber olacak noktaları irdelemişlerdir. (Sancaktaroğlu Bozkurt \& Okyayuz, 2021). Projenin diğer ayağını ise Sağır ve işitme engelli çocuklara yönelik yapılan işaret dili çevirisi oluşturmaktadır. Bu bölümde çevirmen ve sağır anlatıcının çeviri sürecinde etkili erişimi için uygulamada iyileştirme ve öneriler, zorluk ve kısıt durumlarında benimsenecek stratejiler, yaklaşımlar ele alınmış, hem işaret dili çevirmeni hem de Sağır editör için bir kılavuz hazırlanmıştır.

Bu çalışmada söz konusu projenin işaret dili çevirisi bileşeni ele alınarak, proje döngüsü ve çıktısı oluşturulan kılavuz açıklanacak, engelsiz erişim uzmanları ve çeviribilimcilerin ortaya koyduğu verilerden hareketle erişimin sürdürülebilir ve sistematik bir yapıya kavuşturulması amacıyla medya sağlayıcıların çocukların motivasyonunu arttıracak ve ilgi duyabileceği görsel-işitsel ürünlere yönelik tercih çalışmaları yapmalarının önemi vurgulanacaktır.

\section{2. İşaret Dili Çevirisi ve Engelsiz Erişim}

İşaret dilleri, S/sağır ve işitme engellilerin kendi aralarında ve duyan konuşan insanlarla iletişim sağlamak amacıyla ellerin, üst gövdenin ve yüzün kullanıldıkları görsel ve uzamsal dillerdir. İşaret dilleri görsel-uzamsal özellikleriyle işitsel-sözel düzgüyü kullanan konuşma dillerinden ayrııırlar. İşaret dillerini konuşma dillerinden ayıran bir başka özellik ise dilsel yapıların üretim özelliğidir. Konuşma dillerinde ardışık olarak üretilen sesbirim ve biçimbirimler işaret dillerinde eşzamanlı olarak işaret alanı içinde gerçekleşmesidir (Wirth, 2009). Sağır alt-kültürlerin vazgeçilmez parçaları olan işaret dilleri, konuşma dilleri gibi karmaşık bir görünüm sergileyen, dilbilgisel ve anlamsal yapıları bulunan doğal, yaşayan dillerdir (Dikkuya vd., 2015). Bu tanımlama ve özellikler işaret dillerinin sadece jest ve mimiklerden oluştuğu, pantomime benzediği ve de evrensel olduğu gibi bazı ön yargılara açıkık getirmektedir. İşaret dillerinde konuşma dillerinden ayrılan beş temel sesbilimsel parametre bulunmaktadır. Cuxac (1992) bu parametreleri aşă̆ıdaki gibi belirtmektedir:

kullanılmas

- $\quad$ El yönelimi (orientation): Elin yönü (sağ, sol, çapraz, ön, arka, yukarı, aşağı, yan)

- $\quad$ Konum (emplacement): iş̧aretin gerçekleşme alanı (göğüs, bel, baş seviyesi ya da üstü, çene hizası vb.) 
Türkiye'de S/sağır ve İşitme Engelli Çocukların Televizyon Programlarına Engelsiz Erişiminde İşaret Dili Çevirisi Üzerine Bir Araştırma
$\bullet$
Hareket (mouvement): Kolun, bileklerin, parmakların ve elin hareketi
- $\quad$ Yüz ifadesi (expression du visage): Yüz mimikleri, kaş göz hareketi vb.)

Bu dilin kullanıcıları olan Sağır ve işitme engellileri tanımlarken engelsiz erişim için çevirinin söz konusu edildiği bağlamlarda uygulama açısından iki kitle arasındaki ayırım çok önemli olduğu için, "Sağır" sözcüğünün baş harfi büyük "S" ile yazılmaktadır. Bunun nedeni bu sözcüğün işaret dilini öncelikli iletişim dili olarak benimseyerek kullanan ve kendilerini Sağır topluluğa ait hissederek o kültürün özelliklerini yansıtan bireyler için bir kimliğin ifadesi olmasıdır. Bu bağlamda "Sağır" kavramı sosyo-kültürel bir yapıya küçük yazılan "s" ise tıbbi olarak odyolojik bir bozukluğa gönderme yapmaktadır (Gaucher \& Vibert, 2010).

İşaret dillerinin tam ve eksiksiz diller olarak kabul edilmesi zaman almış, günümüze kadar süren dilbilimsel, yapısal, bilişsel vb. birçok alan çalışmasından dolayı son yıllarda çeviribilimin uygulama ve araştırma alanına girmiştir. S/sağır ve işitme engelli topluluğun kullandığı işaret dilleri, günümüzde yasallaştırılmış diller olarak tanınmakta, kimi ülkelerde ise resmî dil konumunda kabul edilmektedir. Örneğin, Türk İşaret Dili (TiD) Türkiye'de bulunan ve yerel alt kültürlerin bir parçası olan Sağır topluluğun kullandığı kendine özgü dilbilgisi, söz varlığı, kullanım özellikleriyle Türk Sağırlarının kültürünü yansıtan doğal, görsel-uzamsal bir dil olarak kabul edilmektedir.

$\mathrm{S} /$ sağır ve işitme engellilerle duyan konuşan bireyler arasında iletişim işaret dili çevirmenleri aracılığıyla gerçekleşmektedir. İşaret dili çevirmeni Séverine Curio (2020, s. 18) profesyonel işaret dili çevirmenini, işaret dili çevirmenliği diplomasına sahip, sözlü çeviri tekniklerine hakim, mesleğini deontolojik ilkeleri doğrultusunda icra eden çift dilli ve kültürlü, iki farklı dil arasında iletişimi dil ve kültür bağlamında sağlayan sözlü çevirmenler olarak tanımlarken işaret dili çevirmenlerinin S/sağır ve işitme engellilerin günlük, toplumsal yaşamlarında her türlü içeriğe erişimini sağlayan aktörler olarak önemli bir rol oynadıklarının da altını çizmektedir. Başka bir ifadeyle engelsiz erişimin kilit kişileridir. Konuşma dilleri arasında çeviri yapan sözlü çevirmenler çeviri sürecinde sadece bir dilden diğerine çeviri yaparken işaret dili çevirmenleri aynı zamanda hem işaret dilinden konuşma diline, hem de konuşma dilinden işaret diline çeviri yapmaktadır. Bu durum çeviri sürecinde farklı bilişsel süreçleri de devreye sokmaktadır.

Tarihsel süreç içinde bütün dünyada işitme engelliler ve dolayısıyla işaret dillerine karşı geliştirilen olumsuz bakış açısıyla bu dillere yönelik akademik araştırma ve çalışmalar da konuşma dillerine göre daha geç devreye girmiştir. Bununla birlikte 21 . Yüzyılda engellileri sosyal yaşama olabildiğince ve daha iyi koşullarda dahil etmek adına yürütülen çalışmalar, Salamanca (1994), Madrid (2002) Bildirileri, Uluslararası Dünya Engelliler Günü (2003) ve Birleşmiş Milletler Engelli Hakları Sözleşmesi (13 Aralık 2006) ve 15 Kasım 2010 tarihinde yürürlüğe giren $A B$ Engellilik Stratejisi gibi uluslararası belgelerde engelliler için daha fazla fırsat eşitliği vurgulanırken hedeflerin somut bir şekilde gerçekleşmesi önemsenmiş, engellilerin televizyon, internet ve medya hizmetlerinden yararlanması ve her türlü içeriğe erişmesi kaçınılmaz bir durum ortaya 
koymuştur. (Neves, 2008). Bu gelişmeler ve toplumun geneline yayılan farkındalık işaret dili çevirmenliğinin dünyadaki gelişiminde özellikle büyük rol oynadığı göz ardı edilemez (Pöchhacker, 1999). İşitme engelli bireyin baskın olan dil topluluğu ile olan iletişimi işaret dilini bilen aile bireyleri ya da yakın çevresi tarafından sağlanabilmektedir. Anne ve babası işitme engelli olduğu halde kendisi duyan ve konuşan çocuklara İngilizce "a child of a deaf adult" tanımlamasının kısaltması olan "CODA" denilmektedir. Codalar hem işaret dilini hem de toplumun doğal sözlü dilini aynı anda edindikleri için iki dilli ve iki kültürlüdür. Codalar kendilerinin deyimiyle görünmez engelleri olan işitme engelli ebeveynlerine, akraba ve yakınlarına yardımcı olarak onların iletişiminde aracı rolünde hem gönüllü hem de zorunlu bir tür çevirmenlik görevi yapmakta, hastane, mahkeme, banka, okul gibi kurumlarda işitme engelli bireyin sesi olmaktadır. (Oral, 2016, s. 96). Bu bağlamda S/sağır ve işitme engelli bireylerin profesyonel iş hayatına ve örgün eğitime entegrasyonunda çevirmenler kaçınılmaz eyleyenler olabilmektedir. Oysa ki, işaret dili çevirisinin yaygınlaşması ve sistematik hale gelmesinin (bir insan hakkı olarak görülmesi) gündeme gelmesi bir toplumun bu bireyleri gerçek anlamda eğitime, hizmetlere erişime, iş hayatına dahil etmeyi ilke edinmesiyle mümkün olacaktır. Bakış açısının değiştiği güne kadar söz konusu dili ana iletişim dili olarak kullanılan kitle, çevresinden aldığı çoğu zaman gönüllülük esasına dayanan yardım ve destekle bir şekilde hizmetlere ve ürünlere erişmiştir, bununla birlikte bu sistematik ve sürdürülebilir bir yapının olmadığına da işaret etmektedir. Ayrıca engelli birey bu yapı olmadan "bağımsız" yaşayamaz ve bu durum söz konusu topluluk için hassas bir konudur. Konuşan işiten toplum açısından çeviri hizmeti bir yardım olarak algılansa da Sağır toplulukların bakış açısından olguya bakıldığında aslında bu yardımdan çok bir erişim gereksinimidir (Napier, 2015, s. 135). Bu bağlamda işaret dili çevirmenleri engelsiz erişimde önemli bir rol oynamaktadır. Engelsiz erişim her türlü görsel ve işitsel ve diğer ürüne erişimi olmayan kişilere erişim sağlamak amacıyla ortaya konmuş bir alandır. Toplumdaki her bireyin anlama ve haberdar olma veya bilgi edinebilme hakkının bir uzantısı olarak, engelsiz erişim, özellikle görsel-işitsel kaynaklara engelsiz erişim çok önemli bir konu olarak 2000'lerden sonra karşımıza çıkmaktadır (bkz. Okyayuz, 2019b). Engellilerin medya ürünlerine erişimi konusunda Avrupa ve Amerika'daki gelişmelere paralel olarak Radyo Televizyon Üst Kurulu (RTÜK) önemli adımlar atmıştır. RTÜK, alanında uzman akademisyenler, ulusal medya sağlayıcı kuruluşlar, $\mathrm{S} /$ sağır, işitme ve görme engellileri temsil eden sivil toplum örgütleriyle görüş alışverişinde bulunmak ve yönetmelik çalışmalarını eşgüdümle yürütmek için Ankara'da 26 Aralık 2018 ve 07 Ocak 2019 tarihleri arasında düzenlediği "Sağırların, İşitme ve Görme Engellilerin Görsel-Işsitsel Medya Hizmetlerine Erişiminin Iyileştirilmesi Çalıştayını 15 Ocak 2019'da yapılan bir toplantıda sunulan bir sonuç bildiriyle sonlandırmıştır. Sonuç Bildirisinin ardından Sağırların, İşitme ve Görme Engellilerin Yayın Hizmetlerine Erişiminin Iyileştirilmesine Iliş̧kin Usul ve Esaslar Hakkında Yönetmelik yayımlanmıştır. Söz konusu alandaki düzenleme olan Sağırların, Işitme ve Görme Engellilerin Yayın Hizmetlerine Erişiminin Iyileştirilmesine Iilişkin Usul ve Esaslar Hakkında Yönetmelik 11 Ekim 2019 tarihli ve 30915 sayılı resmi gazetede ilan edilerek yürürlüğe girmiştir. (T.C. Resmi gazete 2019). RTÜK tarafından kabul edilen Yönetmelik özellikle erişebilirlik konusunda S/sağır ve 
işitme engellilere yönelik özellikle engelsiz erişim alanında çeşitli projeleri, uluslararası çalıştayları teşvik etmiştir.

Erişebilirlik bağlamında görsel-işitsel ürünlerin işaret dili çevirisi farklı becerileri ve yaklaşımları gerektiren bir çeviri türüdür. Özellikle alıcı kitle S/sağır ve işitme engelli çocukları kapsadığında oldukça heterojen bir gruba yönelik bir çeviri söz konusudur. Nitekim çocuklardaki işitme kaybı derecesi, tipi, şekli, kaybın ortaya çıkma yaşı (dil edinimi öncesi-sonrası) vb. faktörlerin yanı sıra işaret dili edinimleri, kültürleri farklılık göstermektedir. Bu bağlamda işaret dili çevirmenin programın türü, içeriğine göre birtakım zorluklar, kısıtlar yaşaması çok doğal bir olgudur. SEBEDER tarafından yürütülen ve tamamlanan "Sağır, İşitme Engelli ve Görme Engelli Çocukların Televizyon Programlarına Engelsiz Erişim Projesi"nin işaret dili çıktısı bu bağlamda işaret dili çevirisini farklı bir boyutta irdeleyerek, çeviri çözümleri, yaklaşımlarına ışık tutarken oluşturulan çeviri kılavuzu da çevirmenlerin mesleki performanslarına da katkılar sağlamaktadır.

\section{Projenin İşaret Dili Bileşeninde Oluşturulan Çevirmen Kılavuzu İçeriği}

Giriş kısmında da belirtildiği üzere ana dilleri işaret dili olan S/sağır ve/ya işitme engelli çocuk alıcılar için işaret diliyle ve/ya ayrıntılı altyazıyla erişebilir çeviri kaynaklar oluşturmak, görme engelli çocuklar için programlara sesli betimleme metinleri eklenmesi için kaynaklar oluşturmak, Sağır, işitme ve görme engelli çocukların birer birey olarak gereksinimlerine hizmet edecek bir proje kılavuzu hazırlamak projenin ana hedefleri arasında yer almaktadır. Bu çalışmada yalnızca $\mathrm{S} /$ sağır ve işitme engelli çocuklar için erişimde işaret dili ayağı üzerinde durulacaktır. Projenin kalitesi açısından güvenilir bir şekilde yürtülmesi, çıktıların bilimsel bir bakış açısıyla değerlendirilmesi ve onanması için TiD-Giç (Türk İşaret Dili Görsel İşitsel Çevirmeni) çevirmenler, Sağır editor/çevirmenler, engelsiz erişim uzmanı ve çevirmen akademiyenler, okul öncesi eğitim uzmanı, çocuk edebiyatı yazarı/çevirmeni/araştırmacısı gibi farklı alanlardan eyleyiciler biraraya gelerek danışmanlık yapmışlardır. Proje sürecinde elde edilen veriler ve dönütlerle akademik açıdan onanmış bir proje döngüsü ve bir çevirmen kılavuzu oluşturulmuş, böylece projenin hedefleri gerçekleştirilmitir. Projenin işaret dili çıktısı ayağında oluşturlan işaret dili kılavuzu, temel yaklaşımlar, çevirmen profili, teknik konular, sorunsallar, standarlar ve örnekler olarar dört ana başlık altında tasarlanmıştır. Temel yaklaşımlarda projenin amacı, ana kısıt, ana sorunsal ve kılavuzun amacı yer almaktadır.

İşitsel düzgüye erişimi olmayan Sağır ve işitme engelli çocukların çocuk programlarına erişim engeli olması, çocuğun toplumla bütünleşmesi, içinde yaşayacağı geniş toplumu tanıması ve kültürlenmesi açısından çok önemli bir sorundur. S/sağır ve işitme engelli çocukların eğitim hayatına da doğrudan etki edecek bu tür ürünler, Sağır ve işitme engelli çocukların 'iki dilli eğitimi' (hem ölçünlü yazı dili -Türkçe- hem de Türk işaret dili edinimi) açısından büyük önem taşımaktadır. Çeviri bağlamında bakıldığında görsel-işitsel ürünlerin işitsel kanalına "sesle" değil de işaret dili ile erişildiğinde, bir işitsel düzgü (üründeki sesler), özünde görsel olan bir 
düzgüyle (işaret dili ile), ikame edilir. Ölçünlü bir dilden (Türkçe) başka bir ölçünlü dile (Türk İşaret Dili- TiD), dillerarası çeviri şeklinde gerçekleşmektedir. Erken yaşta kültürel eğitim, çocuğun toplumdan edinebileceği birikimi zenginleştirecektir ve bu birikimi transfer ederek kişisel gelişimini de katkıda bulunacaktır. Alıcı kitle çocuk olduğunda engelsiz erişimi tasarlarken dikkat edilmesi gereken bazı unsurlar, kısıtlar ve zorluklar bulunmaktadır. Uygulamada, herkes için tasarım (design for all) uygulamasına geçilmediği için çoğu ürünün "işiten dünyaya erişimi olan” çocuğa yönelik olarak tasarlandığının bilinciyle hareket etmek önemlidir. Öncelikle ürünü üreticisi ve alıcısının arasında kültürel olarak örtüşümün tamamen veya kısmen olabileceği gibi çok farklı olabileceğini göz önünde bulundurmak gerekecektir. İki alıcı kitlenin (Sağır ve işitme engelli çocuk ve diğer çocuklar) işiten kültürdeki kültür birikimine, dünya bilgisine erişimi arasında da farklılıklar olacaktır. Sağır çocuğun kendi kültüründe ve dilinde olmayan kavramların ve düşüncelerin, söylem biçimlerinin olabileceği unutulmamalıdır. Bu durumda çevirmen profili ve seçimleriyle editörlerin yetkinliği önem kazanmaktadır. Nitekim çevirmenin yetkinliği işaret dili çevirisinin dışında her anlamda çocuk alıcıda eşdeğer bir erişim sağlayabilecek bir profilde olması bu anlamda çok önemlidir.

Sağır ve işitme engelliler için ayrıntılı alt yazı uzmanlarının da belirttiği üzere (Lorenzo Garcia \& Pereria Rodriguez, 2011; Néves, 2008; Okyayuz, 2019b) hedef kitle oldukça heterojen bir yapıya sahiptir ve her alıcı için aynı tür erişim mümkün değildir. Nitekim bu gurup içinde doğuştan Sağır olanların yanı sıra daha sonra işitme yetisini kaybetmiş bireyler, yarım işitenler ve cihaz kullananlar gibi işitme engelli ve odyolojik sağırlığı olanlar da bulunmaktadır. Ürünü engelsiz erişime uygun hale getirirken, S/sağır ve işitme engelli çocukların bu ürünlerle ilgili motivasyonu ve ürünün cazip hale gelmesi, çocuğun ilgisinin sürekliliğini sağlamak da çok önemlidir. Bu nedenle erişim sadece içerik aktarmanın da ötesine taşındığı için başka yetileri de birlikte işe koşmayı gerektirmektedir. Bu bakış açısından hareketle hazırlanan çevirmenlere görsel işitsel ürünlerin işaret diliyle söz konusu olan kısıtlar (yapılamayacaklar) ve parametreler (olasılık, değişken ve etkenler) ekseninde yol gösterici bir kılavuz hazırlanma amacı güdülmüştür. Bununla birlikte hedef kitlenin heterojen yapısı gibi görsel ürünler de tek tip değildir. Ürünlerin çeşitliliği, karşılaşılacak sorunların çeşitliliği ve bunların değişik parametreler içinde değerlendirilmesinde oluşabilecek farklılıklar göz önüne alındığında bir kılavuzda, çevirmenlerin soracağı tüm sorulara, karşılaşacakları tüm çeviri sorunlarına cevaplar veya çözümlerin yer alması mümkün olmamaktadır. Ancak bu kılavuz genel anlamda çevirmenin zorluklarla baş edebilmesi ve çözüm yolları bulması açısından önemli bir yol gösterici niteliğindedir. Bu kılavuz aynı zamanda görsel işitsel çeviriye ilgi duyan işaret dili çevirmenleri için de önemli bir başvuru kaynağıdır. Kılavuzda yer alan çevirmen profili işaret dili, teknoloji, çeviri süreci, dil, alıcı ve ekip çalışması ile ilgili olarak ele alınmıştır. Çocuklarla yönelik olarak tasarlanmış görsel-işitsel üründe, görsel ürün her şeyden önce bir yan metin daha doğrusu ikonik bir metindir (Cómitre Narváez \& Ruiz, 2019, s. 14). Bu bağlamda konferans, toplum ve diğer çeviri türlerinden farklı olarak işaret dili çevirmeni işaret dili bilgisi ve deneyiminin yanında görsel ürün ve işitsel düzgüyü iletişimsel bir şekilde erişebilir kılma becerisini gerektiren görsel ve işitsel düzgüleri bütünleşik olarak ve 
ayrı ayrı çözümleme, örneğin görselden edinilen bilginin işitselde pekiştirme amacıyla tekrarlanması ile, artık bilgi -fazla bilgi- olarak tekrarlanması arasındaki farkı saptayabilme deneyimine becerisine sahip olmalıdır. Bu becerilerin yanında işaret dili çevirmeni işaret dili çeviri sürecinde kendisine sunulan kılavuzu takip edebilme profesyonelliğine sahip olmalı, işaret dili çevirisi uygulamasının zaman içinde alıcı profilin isteklerine ve özelliklerine, çalışma ve araştırmalara, uygulamada benimsenen esaslara göre evrileceğinin bilincinde olmalı, sürekli mesleki gelişim ilkesini benimseme becerisi ve sözlü dilde sesletimle anlamlanan nida ve ifadelerin aktarılması için ifadedeki (ses tonlamasında) duyguyu işaret dilinde, yüz, mimik, jest ve öykünme yaparak aktarma becerisine sahip olan bir çevirmen profili çizmelidir. İşaret dili çevirmeninin çeviri süreci de kılavuzda yer alan önemli bir bölümdür. Bu süreç işaret dili çevirmenlerinin bilgi ve deneyimlerini ortaya koyarak ürünü erişebilir kılan işlevsel bir aşamadır. Öncelikle işaret dili çevirmeni ölçünlü Türk İşaret Diline (TID) ve alıcı çocuğun "dil birikimine" ve çocuklara yönelik olarak tasarlanan ürünlere hakim olmalı, hitap edilecek çocuk alıcı yaş grubuna uygun olarak duygulara hitap edebilmek için dili kullanabilme (Örneğin, çocuğa komik gelecek unsurları, üzücü gelecek unsurları saptayabilmek), bu ürünlerde ürünün amacını (neden böyle bir ürüne gereksinim duyulduğunu) saptayabilme ve bu saptamadan yola çıkarak ürünün amacını saptırmadan ürünü çevirebilme ve anlam odaklı çeviri ilkesini içselleştirmiş olmalıdır. Kılavuzda belirtilen sorunlu çeviri durumları ile ilgili olarak doğru çeviri seçimlerini yapabilecek diller arası çeviri deneyiminin yanı sıra ürün tasarımında anlamda içselleştirme, çevrilecek ürünü bütünsel olarak inceleme, çeviriyi yapma ve özdenetim sürecini tamamlama gibi profesyonel deneyimi de gözetilmektedir. Çevirmen ürünün taslak çevirisini oluştururken (ön araştırma sürecinde ve çıktısının özdenetim sürecinde) doğru ve kabul görmüş referans kaynaklarını saptayabilme, bunlara erişebilme ve bunları kullanabilmelidir. Çeviri sürecinde bağlam, kısıt ve parametreleri düşünerek gerektiği durumda kaynak metne sadakat gösterebilme, gerektiği durumda da metin uyarlama tekniklerine hâkim olacak ve farklı çeviri stratejilerini uygulayabilecek çeviri birikimine ve yaratıcılığa sahip olmalı, ürün tasarımını yaparken sadeleştirme ilkesini uygulayabilmelidir. Ürünü teslim etmede zaman planlaması yaparak işverenin belirlediği sürede ürünü tamamlayabilecek deneyim ve birikime sahip olan bir profil çizmelidir. Kılavuzda işaret dili çevirmeninin dili kullanma, süreç ve ürüne yönelik çeviri becerilerine paralel olarak alıcı kitle olarak farklı yaş grubundaki çocukların birikimlerini ve profillerini tartabilme ve belli bir alıcıya yönelik olarak ürün tasarlayabilmek için Sağır ve işitme engelli çocukların profilleri hakkında art alan bilgisine sahip olması gerekmektedir. Yetişkinlerin yaşam deneyimi ve kültür ediniminden farklı olarak Sağır ve işitme engelli çocukların dil dağarcığı, sözcük haznesi daha kısıtlıdır. Bu açıdan çevirmenin çocukların sözcük haznesine, sözcük haznesi gelişime ve geliştirme yöntemlerine aşina olması gerekmektedir. Kılavuzda çevirmenin ekip çalışmasına yönelik bazı becerilere de yer verilmiştir. Bu kısımda ürün düzeltiminde editör ile çalışabilme ve geri dönüşleri değerlendirerek bir sonraki uygulamalara yansıtabilme, belli uygulamalarda bir çeviri ortağı ile çalışabilme becerisi (iki çevirmenin aynı ürünün farklı bölümleri üzerinde eşgüdümlü çalışması) ve kendisinden önceki çevirmenlerin ürünlerinden profesyonel 
bilgi edinebilme; edindiği bilgiyi ilkeler halinde düzenlemek ve ilkeleri kendi çevirisinde uygulayabilme becerisinin gerekliliği vurgulanmıştır. Çocukların bir görselişitsel ürünü seçerek sürekli takip etme isteğini etkileyen unsurlardan bir tanesi de bölümlerin bütününde çeviri yapan işaret dili çevirmenidir. Nitekim çocuğu görselişitsel ürüne bağlayan ürünün kendisinin yanında çocuğun çevirmene duyduğu yakınlıktır. Bu nedenle bu ürünlerde tek bir çevirmenin kullanılması, çevirmenin değiştirilmemesi önemlidir. İşaret dili çevirmenine ait görüntünün görsel-işitsel ürün üstünde ekranın minimum 1/8'i ölçülerinde yer alması gerekmektedir ve basene kadar görüntüsünün ekrana yansıması sağlanmalıdır. Çevirmen görüntüsünün ekran üstü konumu standartlarda sağ alt köşe olmalıdır. Görsel bütününde alıcı algısı düşünülerek tüm bölümler boyunca sabit konum kullanılması önerilir. Uluslararası çalışmalarda farklı örnekleri olmakla birlikte görsel-işitsel üründeki detayın kaçırılmaması için ekranda farklı köşelerde kısmi şekilde durması da tercih edilebilir. Bölümler arasında görsel bütünlük sağlanması amacıyla çevirmenin kıyafet, saç stili vb. detaylarda sürdürülebilirlik sağlanmalıdır. Nitekim çevirmenin dış görüntüsü de çocuğun odak noktası olabilmektedir. Bu bakımdan çevirmen kıyafet etiğine uymak durumundadır. Çevirmen çekimleri yüksek kalite kamera ve ışık sistemi ile 'Green Box' uygulaması ile özel stüdyolarda gerçekleştirilmelidir. Işık gölgelerinin benden üstüne yansımadığından emin olunmalıdır.

\subsection{Sorunsallar, Standartlar/Öneriler ve Örnekler}

Bu bölüm altında görsel-işitsel ürünlerin işaret dili çevirisi sürecinde çevirmenin karşılaşacağı bazı zorluklar, sistematik olarak alınması ve uygulanması gereken bazı kararlar, çeviri süreci standartları ve bunlara örnekler sunulmaktadır. İşaret dili çevirisinde her ürün içerik ve türleri farklı olduğundan belli bir mantıkla çevrilmelidir. Burada işaret dili çevirmeni iki ana öğeyi dikkate almak durumundadır. Bunlardan ilki alıcı profilidir. Çevirmen, Sağır ve işitme engelli çocukların yaş gurubuna, söz haznesine, dünya bilgisine, alımlama, öğrenme hızı ve yüküne göre çeviri mantığını ve stratejisini kurgular. İkinci öğe ise ürünün amacı ve içeriği-formatıdır. Ürünün ana amacı çocuğa bir beceri kazandırmaya örneğin, çocuklara el işi öğretmek, çocuklara yemek tarifi vermek gibi bir bilgi aktarmak ve beceri kazandırmak olabilir. Ürünün içeriği-formatında ürünün her bölümde tekrarlanan belli kısımların, bazı alt bölümlerin olup olması çevirmenin çeviri stratejisinde belirleyicidir. Çeviri sürecinde karşılaşılan bazı zorluklar da alıcı kitleye göre şekillenmektedir. Örneğin, İşaret dili çevirisinde çocukların söz dağarcığında olmayan bir sözcük için el abecesi kullanım tercihi ve şeklini alıcı kitle belirler. İzleyici grubun yaşı düşünülerek el abecesi kullanılır. Daha büyük bir yaş grubuna hitap edecek programda 'alıngan otu' gibi çocukların aşina olmayacağı merkezi önemde bir öge el abecesi ile verilmiş, aynı çizgi filmde Amerika'da bir şehir olan 'Brooklyn' ise (merkezi önemde bir öge olmadığı için) sadece ilk harfi (B) ile el abecesiyle ifade edilerek çevrilmiştir. Açımlama ve vurgulamanın verilmesi için zaman kısıtının bulunduğu durumlarda el abecesinin kullanılabilmesi uygun olacaktır.

Kaynak ürünler Sağır çocuklar için tasarlanmamıştır. Bazı durumlarda ürünlerin doğru alımlanması için Sağır çocuklara göre uyarlanması gerekecektir. 
Ancak, her durumda ortaya konan ürünün bir çeviri ürünü olmasına önemlidir. Kılavuzda görsel-işitsel ürünün çevrisinde ürün türüne ve içeriğine göre bazı temel ilkeler ve yaklaşımlar yer almaktadır. Çocukların en çok ilgi duyduğu çizgi filmlerde bazı unsurlara dikkat edilmelidir. Çizgi filmler çocuğa bir mesaj vermek için belli amaçlar doğrultusunda tasarlanmıştır. Çevirmen tarafından bu amaçların saptanması önemlidir. Örneğin Pırıl çizgi filminde matematik öğretildiği için çizgi filmde geçen tüm matematik kavramlarının çevrilmesi gerekir; Şef Roka çizgi filminde yemek yapmak öğretildiği için bütün tariflerin çevrilmesine özen göstermek gerekir. Çizgi filmlerde yer alan giriş jeneriklerindeki şarkılar ve görsellerde içeriğe ilişkin yapılar her bölümde tekrarlandığı için aynı şekilde çevrilmelidir. Kılavuzda çeviri sürecinde 'tutarlılık' ve 'bilgi yüklenmesinden kaçınmak' temel yaklaşımlar olarak ele alınmıştır. Bu yaklaşımların içerikleri aşağıda yer almaktadır:

1)Iş̧aret diline özgü olan anlatı geleneklerini kullanmak

2) Sağır kültürüne (gerektiği yerde ve ölçüde) ürünü uyarlamak

3) Türkçeleştirilmiş işaretten kaçınmak

4) Çocuk alıcının kullandığı ve/ya anlayabileceği bir işaret dili kullanmaya özen göstermek

5) İşaret dili ile çeviri yaparken iletişimsel çeviri yapabilmek için uygun stratejileri kullanmak

6) Görsel-işitsel ürünlerin işaret dili çevirisinde kullanılan çeviri stratejilerinden yola çıkarak (örneğin görseli kullanmak vb.) sade ve iletişimsel bir çeviri sunmak

Görsel-işitsel ürünlerin işaret dili ile çeviri yapılırken ürün aslen farklı bir alıcı kitleye yönelik olduğundan, Sağır kültürünün ve TíD’in içsel bir parçası olmayan bazı durumlarda çevirmen belli yaklaşımları benimser. Bu durumlar aşağıda belirtilmektedir:

1) Ses ve söz oyunları ile oluşan bölümlerin çevirisi (sözlü Türkçeye özgü mani, şarkı, şiir vb.)

2) görsel efektlerle eşleşen (bazı Türkçeye özgü) seslerin çevirisi

3) nidaların ve konuşma dışı insan seslerinin çevirisi

4) bir hareket yapıldığında çıkan sesin çevirisi

5) dış seslerin çevirisi

Çevirmen bu öğelerin çevirisini yine alıcı kitle olan çocukların alımlamalarına, hikâye kurgusuna göre belirler. Bu sesler, hikâye kurgusu içinde merkezi bir öneme sahipse, çeviride aktarılmamaları hikâyenin anlaşılmasını zorlaştırmayacaksa, çevirmenin, sahnedeki hikâye diyalog akışlarının yanı sıra bu sesleri iletecek zamanı varsa ve çocuk alıcı için bu seslerin iletilmesi öğretici olacaksa veya izleme zevkini perçinleyecekse çevirmen tarafından çevrilir. Çocuk alıcının hikâyeyi anlamasının kolaylaşacağı düşünüldüğü durumlarda Sağır kültüre uyarlama yapılabilir. Çocuk 
alıcının söz konusu olan ögeyi daha iyi kavrayacağı düşünüldüğü durumlarda ise açımlama(ögenin kendisini ifade etmeden iki, üç sözle açarak anlatmak) yapılabilir.

Temel yaklaşımlar:

1) Kaynak sesteki yükselmenin veya alçalmanın doğal dil akışında ifade edilmesi: Bu gibi durumlarda çevirmen işaret alanı kullanımını daraltarak ve buna uygun olarak durarak (bedenin kapladığı alanı eğilerek daraltarak) kısık ses veya fısıltıyı ifade edebilir.

2) Kaynak dilde 'duymak' eylemi ile kurulan cümlelerin kurguya uygun olduğu durumlarda 'görmek' eylemi ile ikame edilmesi: Örneğin, 'Ahmet'in arabasına bak. Sen araba aldığını duymamış mıydın?' cümlesindeki 'duymak' fiili 'görmek' fiili ile ikame edilirse daha doğal bir dil akışı sağlanabilecektir.

3) Doğal dil akışının ve kültürlerarası iletişimin sağlanması için kimi zaman tekrarlanan cümleler (Örneğin, Hadi. Gidelim. Gidelim hadi), anlama katkıda bulunmayan cümleler (Ayşe, sen çok yaramazsın. İnanılmaz yaramaz. Çok çok hem de) vb. aktarımda çıkarılabilir ve bunların yerine çocuk alıcının anlamasını sağlayacak açımlamalar veya açıklamalar eklenmesi düşünülebilir.

4) Doğal dil kullanımı bağlamında alıcının yaş grubu önemli bir unsurdur. Örneğin, küçük yaş gruplarına yoğun bir şekilde el abecesi ile aktarım tercih edilmezken, daha büyük yaş gruplarına yeni kavramları öğretmek için işaret dilinde olmayan ancak Türkçede bulunan kavramlar el abecesi ile iletilebilir. El abecesinin kullanımı Sağır çocuğun içinde yaşadığı kültürü edinmesi için doğal bir stratejidir. İletişimsel işaret dilinde de kullanılır.

Örneğin, karakter 'Kermes ne demek?' diye sorduğu için 'kermes' ilk önce el abecesi ile verilir sonra kaynak metinde de olduğu gibi çeviride de açıklanır. Böylece çocuğun söz dağarcığına yeni bir bilgi eklenmiş olur.

5) İşaret dilinde şimdiki, (-dili) geçmiş ve gelecek olarak üç temel zaman kullanılmaktadır. Bu nedenle Türkçenin anlatı geleneğine özgü (-mişli geçmiş zaman gibi) zamanların kullanımından mümkün olduğu kadar kaçınılmalı, işaret dilinde kullanılan zaman kullanımına dikkat edilmelidir.(Örneğin, 'kuru incir bu kış aylarında hastalıklara karşı koruyormuş' cümlesinde 'koruyormuş' yerine 'koruyor' kullanılması.)

6) Kaynak metinde geçen ögenin merkezi önemde olduğu durumlarda el abecesi kullanılmalı ve çocuğa yeni kavramlar ve yeni kelimeler öğretilmelidir. (Örneğin, "ayrıca da kalsiyum deposuymuş, boyunu uzatmak isteyen çocuklar için" tümcesinin çevirisinde kalsiyum vurgulandığı ve önemli olduğu için el abecesiyle yazılır. Tümce ise TiD’ne “incirde kalsiyum, vitamin var. Boy uzatmak isteyen çocuk için” şeklinde çevrilir.

7) Türkçeleşmiş işaretten kaçınılmalıdır.

8) Bazı sessel oyunlar, tekerlemeler ve benzerleri işaret dilinde hafifçe sallanarak (müzikle sallanmak gibi düşünülebilir) verilebilir. 
9) İşaret dilinde doğal iletişimdeki eşdeğerlerin kaynak metindeki sözcükleri ikame etmesi önemlidir. İşaret dilinin doğal akışını yakalamak için belli bir isimlendirme geleneği izlenmelidir.

10) Farklı çocuk alıcı yaş grupları ve ürünlerin özellikleri düşünülerek çeviri stratejileri benimsenmelidir.

11) Farklı çocuk alıcı yaş grupları ve ürünlerin özellikleri düşünülerek çeviri stratejile ri benimsenmelidir. Örneğin, küçük yaş grubundaki çocuklara hitap eden bir çizgi filmde 'Karpat dağları' - 'Romanya, K Dağları (K el abecesi )' olarak verilir. Söz konusu yaş aralığındaki çocukların okuma yazma bildiği düşünülür.

12) Görsel-işitsel ürünün işaret dili çevirisinde görsel düzgüden destek alınarak çevrilecek bölümler olacaktır. Bu doğal dil akışının sağlanmasında önemli bir unsurdur.

a. Örneğin, Hadi karakterinin kucağında önünü görmesini engelleyecek kadar büyük bir çalı yığını olduğu bir sahnede, karakter 'önümü göremiyorum ama düşmediğim sürece sorun değil yani sanırım' der. Işaret diline çevirisinde görsel destek kullanılarak, elinde eşya taşıdığı ve önünü görmekte zorlandığı ve sonrasında da düştüğü anlatılır. Zorlanma sesleri işaretlendirilir.

b. Örneğin, yaygın kullanılan bir işareti olmayan ya da işareti farklılık gösterebilen eşya, şekil, materyal vb.'ini aktarmak için görselden destek alınarak işaretleme yapılabilir.

c. Örneğin, görsel şekillerden yararlanarak 'uzun ve kısa' şekillerinin işaretlenmesi yapılabilir. Eşyanın ya da sembolün şekline, büyüklüğüne göre elin kullanımı ve uzunluğun yatay ya da dikey olmasına göre uzunluk kısalık belirten şekillerin yatay eksende ya da dikey eksende gösterilmesi olasıdır.

13) Merkezi önemdeki dış seslerin çevrilmesi hikâyenin anlamlanması açısından önemlidir. Merkezi önemde olmayan dış sesler ise çevrilmeyebilir.

14) Doğal dil akışının yakalanması için cümle yapılarında değişiklik yapılması çok önemlidir. TiD’in söz diziminin Türkçe'nin söz diziminden farklı olduğu unutulmamalıdır. Sağır kültürünün kullandığı işaret dili dizimi ve ifadeleri kullanılmalıdır.

a. Örneğin, 'Başım belada mı? Bana ne ceza vereceksin?' yerine TiD: 'benim için tehlike (var mı) bana ceza verecek misin?'

b. Örneğin, 'Tek şartım var. Herkes İtirazsız kahvaltısını edecek' yerine TiD:

'şartım var siz kahvaltı kabul yemek

15) Doğal dil akışının yakalanması için, Sağır kültüründeki ifade kalıplarının kullanılması ve kültürel uyarlama yapılması uygun olacaktır. 
a. Örneğin, 'Acaba oksijen yetersizliği mi yaşadım?' yerine: TiD: Nefes yetmedi DÜŞTÜ (nefes nefes (yoruldum anlamında) ve hata yaptım gibi) işaret dili kültürüne ait bir işaret

b.Örneğin, 'ayak izleri' yerine TiD: ayak ve şekli işaret edilir.

16) Doğal dil akışı içinde açımlama yapılarak ve gerekirse cümleler bölünerek (gerekirse birleştirerek) bilginin doğru iletilmesi önemlidir.

a. Örneğin, 'Ayağı sıkışmış' yerine TiD: 'ağaç düşmüş bacak ağaç altında çıkmıyor.

b. Örneğin, 'Sabredin biraz' yerine TiD: 'sabır bekle'

17) Çevirmen, alıcı kitle tarafından metnin anlamının algılanacağı bir çeviri stratejisi bulamadığı durumlarda, ses ve/ya söz oyunlarının çevirisinde 'anlam odaklı' yaklaşımı benimser. Gerekirse, ses ve/ya söz oyununu çıkartır.

18) Metindeki duygunun aktarımını sağlayan dil dışı insan seslerinin çevrilmesi önemli olabilir. Örneğin, bir hareketi yapmakta zorlanan bir insandan çıkan ses, kahkaha, şaşırma vb. seslerin çevirisi görselde bu unsur belirtilmiş olsa bile tercih edilebilir.

19)TiD’de yarım kalan cümlelerin anlaşılmayacağı düşünülerek metinde merkezi önemde olan yarım kalan cümleler (tamamlanmayan cümleler) tamamlanarak aktarılabilir.

20) TiD’in, (örneğin) çarpma olgusu ya da patlama olgusu gibi Türkçede 'sesle' ifade edilen olguları ifade edebilecek bir haznesi vardır. Bunların çeviride de yansıtılması ve kullanılması gerekir.

a. Örneğin, bir sahnede çarpışma gözükmüyor ama çarpışma sesi geliyor. Çevirmen işaret ile çarpmayı ifade eder; sonrasında gelen görselden destek alınarak çarpma şeklini, vs. ifade eder.

21) Bazı durumlarda söz konusu öge merkezi önemde olduğunda ve kavramın aktarılması gerektiği durumlarda çevirmen yaratıcılığını kullanarak bir ögeyi aktarmayı seçebilir. Örneğin, görselden de destek alıyorsa 'Flamenko dansı'nı öykünerek işaretleyebilir.

Öykünme. Öykünme, çocuklara özgü çizgi filmlerde işaret dili çevirmeninin ilettiği karakter, koşul, ortam vb.'ine ilişkin olarak duyguları yansıtabilmesi için beden dilini, mimiklerini vb.'ini kullanarak bir bilgiyi aktarmasına verilen isimdir. Öykünme bir karakterin duygusunu, bir ortamın kurgusunu ve atmosferini aktarmak, çocuk alıcının ürünün sessel düzgüsünden iletilen bilgiden edinilen duyguya erişimini sağlamak için kullanılır.

İşaret dili çevirmeni aşağıdaki durumlarda öykünmeyi kullanabilmektedir:

1) Karakterlerin duygularını yansıtmak için öykünmeyi kullanabilir (Örneğin, korkan bir karakterin duygularının yüz ifadesi ve beden diliyle -'ay' gibi nidaların amaçladığı anlamı da içerecek şekilde- aktarımı) 
2) Özellikle insan olmayan karakterlerin yüz ifadeleri seçilmediği ve duyguları (ağırlıklı olarak) sessel düzgüden iletildiği durumlarda çevirmen öykünmeyi kullanabilir (Örneğin, atların geçtiği bir çizgi filmde yüzleri çok fazla belli olmadığı için ses tonlarına yansıttıkları duygular işaret dili çevirmeni tarafından yüz mimikleri ile ifade edilir)

3) Genellikle, nidalar ve dil dışı sesler öykünme ile verilir. Örneğin, karakterin esneme sesi, nefes sesi vb. veya 'ay' gibi korku nidaları, 'aaa' gibi şaşırma nidaları vb.

4) 3. Şıkta değinilen dil dışı sesler karakter sesleri olmayabilir; doğa sesleri de olabilir. Aynı yaklaşım kullanılır. Örneğin, şimşeklerin çaktığı yağmurlu bir havadaki atmosferin öykünmeyle -beden diliyle ve mimiklerle- aktarımı; baykuş sesleri ile dolu karanlık bir gecedeki atmosferin baykuş sesi ve öykünme ile verilmesi.

5) Karakterin ses tonu öykünme ile yansıtılabilir. Örneğin, yüksek sesle, enerjik bir şekilde konuşan karakterin bu sessel özelliğinin öykünme ile yansıtılabilir.

Konumlandırma Yapmak. Görsel-işitsel ürünlerin işaret dili çevirisinde konumlandırma yapmak, işaret dili çevirmeninin 'sessel ögenin' (karakterin konuşması, sesin geldiği yer -dış ses, telefondan gelen ses-, jenerik müziği veya fon müziği olarak kullanılan ses vb.) kime ve/ya neye ait olduğunu alıcıya iletmesi için kullanılan bir tekniktir.

Konumlandırma:

1) Hangi karakterin konuştuğunu belli etmek,

2) Sesin kaynağını (sessel düzgüde aktarılan bilgiyi) belli etmek,

3) İletişimin aktörlerini ve/ya sessel iletişimle iletilen bilgiyi çocuk alıcıya iletmek için kullanılır.

Konumlandırmada çevirmenin karşılaştığı zorluklar aşağıda belirtilmektedir:

1) Birçok karakterin iletişim içinde olduğu sahnelerde çevirmen hepsinin konumunu iletmekte zorluk çeker.

2) Sahne çekimlerinde değişiklik olduğunda bu çevirmen açısından zorlayıcı olabilir. Örneğin, konuşmaya başladığında yüzü görünen ve ekran solunda yer alan bir karakter konuşmaya devam ederken arkadan çekime geçilir ve konumu değişirse çevirmenin konumlandırma ile ilgili bir karar vermesi gerekir.

3) Karakter sahne içinde hareketliyse (konumu değişiyorsa) bu da çevirmen için zorlayıcı bir unsurdur.

4) Çok fazla sayıda karakterin hareketli olduğu durumlarda konumlandırma sorunlu bir konudur. Örneğin, görselde hızlı geçişlerde ve görselde değişimlerde konumlandırmalar her zaman doğru tarafta yapılamayabilir. Bu gibi durumlarda, belirlenen kişilerin konumu her zaman aynı tarafta korunmalıdır; çünkü alıcılar sessel düzgüyü takip edemedikleri için karışıklık olabilir. Ayrıca, çevirmenin çok hızla hareket etmesi ve sürekli konumu değiştirmesi kafa karışıklığına neden olabilir.

Konumlandırma yapacak olan işaret dili çevirmeninin aşağıdaki noktalara dikkat etmesi 
gerekir:

1) Konumlandırma her zaman çok belirgin bir beden hareketi ile yapılamayabilir (özellikle de hızlı sahne değişimlerinde). Konumlandırmanın 'belirginliği' üründen ürüne veya sahneden sahneye değişebilecektir. Örneğin, bir üründe her bölümde görselde en az 3 (hatta bazen daha fazla sayıda) ana karakter / kişi olduğu bir durumda kişiler sağ, orta ve sol şeklinde konumlandırılır.

2) Ancak, her zaman asgari bir konumlandırma yapılması çocuk alıcının bilginin kaynağına erişmesi için önemlidir.

3) Bazen sahne başındaki konumlandırma çekim açısının değiş̧mesine göre değiştirilecektir, bazen de sabit kalacaktır.

a. Konum değiştirmeye örnek: Telefonun çaldığı bir sahnede ilk olarak gövdenin hafif dışarıya doğru konumlandırılması ve "telefonda" işareti ile telefondan gelen sesin belirtilmesi, daha sonrasında telefondaki sesin sahibi ekranda görünürse konuşanların konumuna göre konum alınması düşünülebilir.

b. Illk konumlandırmayı korumaya örnek: Teo araba içinde hikayesini anlatmaya başlar. Görselde Teo görülür. Ancak, sahnenin devamında Teo hikayesini anlatmaya devam etse de görüntü değişmeye başlar. Bu gibi bir örnekte (Teo dış ses anlatıcı olduğunda) çevirmen duruşunu, konumunu ve ifadesini hiç değiştirmeden çevirisine devam eder. Bu örnekteki uygulamayla aynı kişinin konuştuğu, konuşmanın devamlılığı hissettirilir.

Konumlandırmada temel konular:

1) Karakterin ekranda durduğu yer temel alınır. (Örneğin, bir grup atın tepede, bir grup atın ise ovada durduğu ve iletişim kurduğu bir sahnede, çevirmen aşağıdan seslenen atların konumu ve yukarıdan cevap veren atların konumları dikkate alınarak konumlandırılır.)

2) Karakterlerin ekranda durdukları yerlerin beden diliyle belirtilmesi esasken, bazı durumlarda konumlandırma el hareketleri ile de yapılabilir .

3) Çevirmen ekrandaki görüntüsünün bir yansıma olduğunu unutmamalıdır:

a. Özellikle görseli işaret edeceği durumlarda (ekrandaki bir bilgiyi işaret edeceği durumlarda),

b.Yön belirteceği durumlarda (örneğin, kuzey, güney, doğu, batı yönleri çevirmenin kendi konumuna ve montaj sonrası ekrandaki konumuna göre yönlerin bulundukları taraf gösterilerek ifade edilir) doğru konumlandırma yapmaya özen göstermelidir.

4) Konumlandırma bazen de hikâye anlatısını aktarmak için kullanılabilir. Örneğin, yağmur yağmış ve bir ağacın bir tarafında yosun oluşmuştur. Bu örnekte, rüzgâr yönü ve yağmurun yağdığı yön ve oluşan yosunun bulunduğu taraf bağlantılı olduğu için yön konumlandırmaları bu bilgiler dikkate alınarak çevrilir. Çevirmen koluyla ağacı belirtir, 
diğer eliyle yağmurun ağacın yosun tutan tarafına yağdığını gösterir.

Karakter Isimlerinin Belirlenmesi/Belirtilmesi. Kişilerin, hem yazılı iletişim kullanılan resmi ismi, hem de işaret ismi olduğu göz önünde tutularak, Sağır kültürüne yönelik çeviri yapılırken, karakterlerin isimlerinin sürekli harf harf dökümle (el abecesi ) yazılmaması ve karakterlere bir işaret adı atanması doğru olacaktır.

ilkesel olarak:

1) Sağır kültürde işaret ismi verme geleneklerine uygun olarak, işaret adının karakterin bir fiziksel vb. özelliğine uygun olarak verilmesi gerekir.

2) Ürünlerdeki, (özellikle başrolde yer alan) karakterlerin bir işaret ismi olmasıçocuk alıcının ürünü takip etmesini ve doğal dil akışını (işaret dilinin ölçünlü kullanımını) destekleyecektir.

3) Özellikle başrol karakterlerine verilen isimlerde, bu işaret isminin daha önce başka bir başrol karakterine verilmediğine emin olmak önemlidir. Aksi durumda, karakterleri ayrıştırmak zorlaşacaktır.

4) Ayrıca, karaktere verilen işaret ismi bir 'marka' gibi düşünülürse aynı ürünü çevirecek tüm çevirmenlerin bu işaret ismini kullanmaya özen göstermeleri önemlidir.

a)Karakter isimlerinin belirlenmesinde bazı kısıtlar söz konusudur. Bu kısıtlar görselde kimin konuştuğunun açıkça belli edilmediği durumlarda, çocuk alıcının görsele yeterince dikkat edememesi durumunda ve dış seslerin olduğu kurgularda ve benzeri durumlarda alıcı açısından 'kimin konuştuğunun' ayrıştırılması da önemlidir. Bu durumlarla aşağıdaki öneriler çevirmene yol gösterici olabilir: a) karakterin belirtilmesi gerekmektedir

b) karakterin görünüp görünmediğini,

c) kimin konuştuğunun belli olup olmadığını vb. tartarak, çevirmenin bir seçimi yapması gerekir.

Ancak, bazı 'karakter isimleri' lakap olabilir (Burnu akan bir çocuğa arkadaşlarının 'AKıŞKAN' adını takması gibi) veya örneğin o karakteri betimlemeye yönelik olarak türetilmiş 'uydurulmuş bir isim' olabilir. (Örneğin, bir programda sunucuya eşlik eden 'bilgisayar/robot' benzeri bir karaktere 'DÖNÜşTÜRATÖR' isminin verilmesi gibi.) Bu gibi durumlarda çevirmenin bir seçim yapması gerekir: Seçimlerini aşağıda belirtilen parametreleri kullanarak yapabilir:

Sözü edilen karakter için kullanılan 'isim' göndermesiyle birlikte alıcı kitle için anlamlıysa aynıyla yazılır: Örneğin: Çok hızlı koşan veya tepki veren bir robotun adı IŞıK HIZI ise bu isim aynıyla kullanılabilir. Söz konusu yaş grubunun 'ışık hızını' bildiği varsayılıyorsa ve ismin kullanımı eşzaman kuralına uyuyorsa, o zaman bu ismin aynıyla bırakılması bir sorun yaratmayacaktır.

Sözü edilen karakter için kullanılan ismin alıcı kitlede karşılığı yok ise ve ismi anlaması zor olacak ise değişiklik yapılabilir. Örneğin, program sunucusu ile interaktif 
olarak programda yer alan 'DÖNÜŞTÜRATÖR' adı verilmiş 'karakter', sunucuya el işi projeler yapması için belli şekillerde 'dönüştürebileceği malzemeler' hakkında ve bu malzemeleri nasıl kullanabileceğine dair bilgi vermektedir. Karakter ismi alıc kitle tarafından anlaşılmayacağı düşünülüyorsa, bu gibi durumlarda kapsayıcı tabir kullanılması düşünülebilir. Örneğin, ROBOT.

Uydurulmuş isim veya lakaplarda anlama: Bir karaktere bir lakap takılmışsa, eğer programda karakterin gerçek ismi de geçiyorsa, çocuk alıcıda kafa karışıklığı yaratmamak amacıyla karaktere belirlenen işaret dili ve ona takılan takma ismin farklı olmasına dikkat edilir.

Örneğin, Teo sarışın bir çocuk olduğu için işaret dilinde adı 'sarı saçlı' olarak belirlenmiştir. Ancak, arkadaş grubunda lakabı 'akıntı' ve lakabı çok sık geçer ve konu bu lakabından kurtulmak üzerinedir. Bu gibi durumlarda alıcının bu ayrımı anlayacağı varsayılır ve çeviride her iki isimde kullanılır.

İşaret ismi belirlemede önemli konular:

1) İşaret ismi belirlenirken karakterin bir fiziksel özelliğine göre belirleniyorsa başka karakterlerin ismi ile örtüşmemesine dikkat edilir:

Örneğin; Pırıl ve Yade çizgi filmlerinde başrolde at kuyruğu yapmış kızlar vardır. Ayrıştırılmaları için YADE at kuyruğu ile, PIRIL topuz ile işaretlendirilmiştir.

2) Tüm ana karakterlere ve tekrarlanan karakterlere işaret ismi verilmelidir:

Örneğin, Şef Roka ve Hadi, Şef Roka çizgi filmdeki ana karakterlerdir. Şef Roka için ilk geçtiği bağlamda "Aşçı" işareti ile el abecesiyle "Roka" diye belirtilen karakter daha sonra Aşçı (işaret) R (el abecesi) ile ifade edilmiş, Hadi karakteri ise görselde belirgin olarak öne çıkan fiziksel özelliğinden yola çıkılarak 'Kırmızı Bıyık' olarak işaretlenmiştir.

Örneğin, başrolde atların olduğu bir çizgi filmde atların görsel özelliklerine göre (gözleri, renkleri vb.) işaret adı verilebilir.

3) Çocuk çizgi filmlerinde sıkça geçen 'hayal ürünü' karakterlerin işaret dilinde isimlendirilmesinde:

a. İlk olarak bu hayal ürünü varlıklara kapsayıcı bir işaret ismi verilir (Örneğin, Yade çizgi filminde Mati'leri belirtmek için bir işaret belirlenmiştir)

b. Kapsayıcı isim altında aynı türdeki farklı karakterleri ayrıştırmak içinse yine karakterlerin fiziksel özellikleri kullanılır (Örneğin, Yade çizgi filmindeki Mati'ler renklerine göre isimlendirilmiştir-TiD'de MAVi)

4) Tekrarlanmayan veya merkezi önemde olmayan karakterler için çevirmen birkaç farklı çeviri stratejisi kullanabilir:

a. Kişinin adının baş harfini el abecesi ile yazarak karakteri belirtmek (Örneğin, Şef Roka çizgi filminde her bölümde değişen karakterler için bu gibi bir 
Türkiye'de S/sağır ve İşitme Engelli Çocukların Televizyon Programlarına Engelsiz

Erişiminde İşaret Dili Çevirisi Üzerine Bir Araştırma

yaklaşım kullanılabilir)

b. Kişinin ana karakterle olan bağlantısını belirterek karaktere işaret etmek (Örneğin, başrol karakterinin annesi için ANNE işareti; Şef ROKA'nın yardımcısı olan Amber karakteri için YARDIMCI işareti; ana karakterlerin bir arkadaşına ARKADAŞ işareti vb.)

c. Karakterin vasfı veya kapsayıcı isim kullanarak belirtmek (Örneğin, Pırıl çizgi filminde öğretmen karakterine ÖĞRETMEN işaretinin kullanılması vb.)

d. Karakter tek sahnede geçiyorsa ve konuştuğu belli oluyorsa ve bu karaktere bir gönderme yapılmıyorsa, sadece diyalogları çevirmek ve karakterin ismini belirtmemek (Örneğin, bir çizgi filmde geçen Gelincik tek bir sahnede görünür ve konuşur. Bu karaktere bir işaret ismi verilmemiştir.)

5) Karakter isimleri ile söz oyunu yapıldığı durumlarda, çevirmen isimleri aktarırken söz, ses oyunu vb.'ini de aktarmayı seçebilir.

Örneğin, bir çizgi filmde Kuti, Ayba, Rubi, Enda gibi yabancı isimler geçmektedir. İsimlerinin baş harfleri birleştirildiğinde ise KARE sözcüğü oluşmaktadır. Çevirmen, çizgi filmin adı da olan KARE ögesini korur ve karakterlerin işaret isimlerini el abecesiyle K A R ve E harfleriyle verir. Bu stratejinin tercih edilmesinin bir nedeni de karakterlerin isimlerinin çizgi filmde geçen 'haber zamanı' kesitlerinde ve kurgu içinde göreve gidecekleri kesitlerde şarkı söylenirken görselde de belirtilmesidir. Dolayısıyla, isimlerin göndermesi olan KARE ögesini yansıtmak, görselle bilgiyi birleştirmek vb. amaçlarla bu strateji benimsenebilir.

Nidaların çevirisi. Sözlü dilde vurgu, sesletim ve benzeri ile anlamlanan nidaların işaret dilinde yansıtılmasında dikkatli olmak gerekir.

Bu tür nidalara aşina olmayan çocuk alıcılar için nidaların el abecesi ile ifade edilmesi kafa karışıklığına neden olmakta, kimi zaman da ürünü anlaşılmaz kılmaktadır.

1) Nidalar yüz ifadesi (mimik ve jestler) ile ve gerekir ise işaret dilinin desteği ile yansitılır.

Örnek 1:

A: Ayşe okula gitmedi.

B: Aa.. (şaşırma yüz ifadesi - kaşlar kalkar, baş öne doğru gelir ve ağız açık kalır

A: Ayşe okula gitmedi.

B: Aa.. (sinirlenme yüz ifadesi ve el işareti - kaşlar çatılır, baş öne doğru gelir ve el ile ne oluyor şeklinde bir hareket yapılır)

A: Ayşe okula gitmedi.

B: Aa.. (kötü olmuş, ne kadar yazık olmuş yüz ifadesi ve el işareti - dudaklar büzüşür, el ile tüh işareti yapılır) 
2) Çevirmenin, yukarıda verilen örnekteki nidadan da anlaşılacağı üzere, üç seçeneği vardır:

a) Nidayı dudak şekli ile ifade edip ek olarak yüz ifadesi ile destekleyerek aktarmaktır.

b) Nidanın 'amacını' yansıtarak açımlama tekniğini kullanmaktır. Örneğin, 'ah, unuttum' yerine 'tüh, unuttum. Özür dilerim/üzgünüm' şeklinde çevrilmesidir.

c) Nidayı tamamen çıkartmaktır. Burada çevirmen bağlam, iletişim durumu ve nidanın kullanımsal değerine dikkat etmelidir. Nitekim nidanın çıkarılması anlamı ve duygu değerini destekleyici bir unsur olabilir.

Nidaların çevirisinde çevirmenin çeviri seçiminde aşağıdaki parametreler devreye girmektedir:

a. Nida yansıtılmazsa (çıkarılırsa), metinde (üründe) bir anlam kaybı veya ifadedeki duygu yükünde (üzüntü, sevinç vb.) bir farklılaşma oluyor mu?

b. Nida olduğu gibi yansıtılamıyor veya çıkarılamıyorsa, bu nida metinde hangi duyguyu, düşünceyi vb.'ini ifade ediyor ve işaret dilinde nasıl yansıtılabilir?

Diyaloglar Dışındaki Sessel Ögelerin Çevirisi:

Çocuklara yönelik ürünlerde (çoğu diğer görsel-işitsel üründe olduğu gibi) diyalogların dışında da sessel ögeler bulunmaktadır.

Çevirmen, bu ögeleri:

1) Merkezi önemde olduklarında,

2) Zamansal kısıt olmadığında,

3) Ürünün atmosferini (artalanını) belirlediğinde,

4) Hikâye kurgusu içinde anlamlanmayı sağladığında, vb. çevirmelidir.

Bu tür sesler:

1) Görsel efektlerle birleşen (doğal veya doğal olmayan) sesler,

2) İnsanların seslettiği duygu sesleri,

3) Hayvan sesleri,

4) (Insanların veya aletlerin vb.) hareketleri ile çıkan sesler,

5) Müzik,

6) Şarkı, vb. olabilir.

Temel yaklaşımlar:

1) Söz konusu sesin işaret dilinde bir karşılığı varsa bu kullanılmalıdır:

a. Örneğin, 'telefon çaldı' yerine TíD: telefon titreşim 
2) Söz konusu ses bir hareketin sesi ise harekete öykünerek çıkan ses aktarılır:

a. Örneğin, 'ayak sesleri'

3) Söz konusu ses bir müzik ise müziğin atmosferine (neşeli, korkutucu) öykünerek ve müzik olduğunu belli etmek için sallanarak veya hareket ederek aktarılır.

4) Söz konusu ses bir dış ses ise:

Dış sesin geldiği yeri belli edecek konumlandırma eşliğinde iletilir. Örneğin, bir çizgi filmde her bölümün sonunda yolda karavan içerisinde konuşmalar geçer. Konuşmaların araba içinden geldiği belirtilmeye çalışılır ancak kimin konuştuğu belli olmaz. Ama bir 'dış ses' olduğu bellidir.

Şarkıların/müziklerin işaret dilinde yansıtılması:

Sağırlar her ne kadar işitme duyuları olmasa da şarkı, müzik ve dans kavramları kendi kültürlerinin bir parçasıdır. Duymadıkları için ritm, müziğin yansıttığı titreşim hissi bu duyular etkilidir. Bazen de müzik varsa ve çevirmen müzik süresince ekranda sadece duruyorsa ekranda bir görüntü kirliliği olur. Bu nedenle aktarım tercihleri önemlidir.

Dolayısıyla, gerek şarkı sözlerinin yansıtılmasında gerekse jenerik veya geçiş müziği olarak kullanılan sessel öğelerin yansıtımında çevirmenin bazı seçimler yapılması gerekir. Çevirmen bu seçimleri yaparken bazı kısıt (yapılamayacaklar) ve parametreleri (olasılıklar, değişkeler ve etkenler) düşünerek hareket etmelidir.

1) Şarkı/müzik ürünün anlamlanması için merkezi önemde midir?

a) Sahne geçişleri: Örneğin, bir sahneden bir diğerine geçerken ürünün jenerik müziği çalıyorsa ve aynı zamanda görselde de bir sahne geçişi görünüyorsa, çevirmen bunu yansıtmamayı seçebilir. Çocuk alıcı görselden sahnenin değiştiğini anlayacaktır.

b) Sahne atmosferi: Örneğin, bir sahnede çocuklar oyun parkında çok eğleniyorlar ve fonda sözleri olmayan neşeyi, eğlenceyi çağrıştıran bir müzik çalıyor. Bu 'sessel' öge atmosferi yarattığı için önemli görülebilir. Bu durumda, çevirmenin bu şarkının yarattığı atmosferi sevinç, mutluluk çağrıştıran enerjik dans hareketleri ile belirtmesi gerekir. Bu gibi durumlarda en önemli sahneler; şaşırma, korku, gerilim gibi meraklandıran sahnelerdir.

c) Sahne atmosferini etkileyen müzikler karakterlerin duyguları ifade edilerek de yansıtılabilir. Örneğin; fonda gerilim müziği çalmaktadır ve görselde ormanın içerisinde yürüyen bir çocuk görünür. Çocuk korkmaktadır, müzik de 'korku' ögesini desteklemektedir. Bu durumda çocuğun korkusu yansıtmak için çevirmen, yüz ifadesini temkinli ve ürkek adım atma şeklini bedeninin konumu ile hatta efekt sesleri (ayak sesleri vb. gibi) ekleyerek belirtebilir.

2) Şarkı, hikâye örgüsüne bir art alan bilgisi ekliyor veya hikayedeki bir konuya vurgu/ekleme/açıklama getiriyor mu?

a. Jenerik şarkıları: Bazı jenerik şarkılarında, üründe anlatılacak karakterler veya 
olaylarla ilgili bilgi verilebilir. Örneğin, Rafadan Tayfa çizgi filminde jenerik şarkısında Rafadan Tayfa'nın nasıl bir grup olduğu ve ne yaptıkları anlatılmakta ve hikâyeye bir giriş sunulmaktadır. Bu gibi bağlamlarda sadeleştirme yaklaşımı kullanılarak, şarkı geleneğindeki tekrarlar aza indirgenerek, anlamı bozmadığı ve işaret dilinde (Sağır kültür dikkate alınarak - Türkçeleşmiş işaretten kaçınılmaya özen gösterilmelidir) aktarılacak şekilde kurgulanarak uyakları aynıyla aktarmaya özen göstererek çeviri yapılabilir.

b._Hikâye kurgusu içinde şarkılar: Bazı ürünlerde, karakterler bir şarkı söyleyebilirler ya da fonda bir şarkı çalar ve bu şarkı hikayedeki bir unsuru vurgulamak için kullanılır.

Örneğin, yalancı bir karakterin anlatıldığı bir bölümde karakterin arkadaşları Yalancı Çoban şarkısını söyleyebilirler veya şarkı (sözleriyle birlikte fonda çalabilir). Bu gibi durumlarda çevirmenin belli seçimler yapması gerekir. Çevirmen, şarkının sözlerini yansıtabilecek uzama ve zamana sahipse, anlamsal çeviri ilkeleri doğrultusunda şarkı sözlerini çevirecektir.

3) Şarkı veya müzik ögesinin tamamen çıkarılması metnin anlaşılmasını zorlaştırıyor veya izleme zevkinden eksiltiyor mu?

a. İlkesel olarak, hiçbir sessel ögenin metinde işlevsiz olduğu düşünülmemelidir. Asgari bir anlatıyla da olsa (örneğin, şarkı adı, şarkı ana fikri, şarkı olduğunun ifadesi vb.) aktarılması gerekir.

b. İlkesel olarak, söz konusu sessel öge alıcının ürünü anlamasında merkezi öneme sahip değilse, çocuk alıcıyı gereksiz yere tekrarlarla sıkmamak gerekir. Bunun yerine çevirmen çevirisini kısaltabilir. (Örneğin, bir şarkıda aynı satırın 5 defa tekrarlanması gereksiz olabilir.)

Söz/ses oyunlarının yansıtımı.Ürünlerde geçen söz oyunlarının veya sesteş sözcüklerle yapılan oyunların yansıtılması çevirmen için (kimi bağlamda) sorunlu olabilir.

1) Şarkılarda ve benzer sessel ögelerde uyak gibi unsurların yansıtılması önemli olabilir; ama her zaman anlam merkezi önemde olacaktır. Bu gibi durumlarda çevirmenin seçimler yapması gerekir.

2) Çift anlamlı sözcükler/kullanımlar: Örneğin, bozuk para ile 'yazı-tura' oynayan çocukların anlatıldığı bir sahnede çocuklar bozuk parayı fırlatıp 'yazı' veya 'tura' derler. Para üç defa üst üstte yazı gelir. Bir çocuk da hep tura demiştir. Çocuk sinirlenir ve 'Bu 'bozuk' para' veya 'Bu para 'bozuk' diye hem 'bozuk paraya', hem de paranın hep yazı gelmesine göndermede bulunup espri yapar. Bu gibi durumlarda çevirmen söz konusu ögeyi vurgulamak için bir yol bulabilir: Örneğin, hem işaret dilindeki yuvarlak para kelimesini hem de Türkçede kullanıldığını belirtilerek bozuk para işaretini kullanır ve açımlama yapması gerekebilir.

3) Çocuk alıcının sözcük dağarcı̆̆ı: Bazı durumlarda ise çocuk alıcının sözcük dağarcığı çevirmeni kısıtlayabilir. Ürünler çocuk alıcıya uygun olarak tasarlanmış olsa bile, yaşıtları ile aynı oranda dış dünyaya erişimi ya da kaynaşma olanağı olmayan çocuk alıcılar için kullanılan sözcükler zorlayıcı olabilir. 
Yukarıda örneklenen durumlarda çevirmenin sözcüğün TíD karşılığı olsa da ve bu eş sesli olsa da anlama göre farklı işaretlendirilmesi durumunda anlamı ne kadar koruyabildiğini değerlendirerek açımlama yapması gerekebilir. Sözlü dilde/argoda kullanılan deyişlerin hedef çocuk alıcılar tarafından bilinip bilinmeyeceğinin tartılarak, görseldeki bilginin konuyu ne kadar açık ortaya koyduğu göz önünde tutularak, diyalogların devamından söylenenin anlaşılıp anlaşılmayacağı düşünülerek uygun bir çeviri tekniği benimsenmesi gerekir. Çevirmen bazı durumda ögeyi aynıyla bırakmayı, kimi zaman metinde vurgulamayı, kimi zaman da uyarlayarak çevirmeyi seçebilecektir.

Uyak merkezi önemde değilse, uyağın değil, anlamın yansıtılması öncelik kazanacaktır. Alıcının yaşına göre anlaşılacağı düşünülür ise el abecesiyle çevrilmesi tercih edilebilir. Örneğin, ana - dana vb.

Bölüm başlıklarının/görseldeki yazıların çevirisi. İlkesel olarak bölüm başlıkları, görseldeki yazılar gibi ögeler görselde yer alsa bile işaret dilinde yansıtılması (tekrarlanması) önemlidir. Zaman kısıtlaması ve konu içerisindeki önemine ve anlamın etkisine göre çevrilmemesi tercih edilebilir.

Yeni sözcükler: Çocuklar programları izleyerek yeni sözcük ve kavramları öğrenirler. Ancak, dış dünyaya erişimi akranlarına kıyasla daha az olan bir çocuk tarafından bu kavram bir çocuk tarafından bu kavramların algılanması kimi zaman daha güç olabilmektedir. Aynı mantıktan hareketle, sözü edilen çocuğun sözcük dağarcığı da daha dar olabilecektir. Dolayısıyla, yalnızca programda öğretilen yeni kavramlar değil, programda geçen başka kavramlar da çocuk alıcı için 'yeni sözcük/kavram' olabilecektir.

1) ilkesel olarak, çocuk alıcının sözcük veya kavram dağarcığını genişletmek için ürüne eklenmiş olan sözcüklerin el abecesiyle aktarılması (sadeleştirme ve silme yapılmaması) önemlidir. (Örneğin; bir el işi anlatısında hobi tutkalı, pastel boya, keçeli kağıt... vb. gibi) Programın amacı çocuk alıcıya bunları öğretmekse, çevirmen bu gibi ögeleri ilk geçtikleri yerde el abecesiyle çevirir. Illk geçtiği bağlamda parmak alfabesi ile ifade edilen sözcükler/kavramlar devamında işaretlendirilerek ya da kelimenin baş harfi kullanılarak belirtilebilir.

2) Sağır veya işitme engelli çocuğun, çevresindeki dünyaya ve dolayısıyla dünya bilgisine erişiminin daha kısıtlı olabileceği, eğer söz konusu çocuğun ana iletişim dili Türk işaret dili ise kültüründe veya işaret dilinde bazı kavramların farklı şekilde ifade edildiği veya olmadığı gibi farklılıklar göz önüne alınmalıdır. Böylece alıcı çocuğun sözcük haznesi de gelişecektir. Çevirmenin bu kavram ve sözcüklerin el abecesiyle iletimini 'makul bir oranda' tutması önemlidir. Programdaki yeni sözcük/kavram sayısına göre çevirmenin bazı kavramları veya sözcükleri çocuk alıcının anlaması için eşdeğerleriyle karşılaması söz konusu olabilir.

Sayıların ifadesi:

Çevirmen sıralı sayı dizimi söz konusu ise soldan sağa konumlandırarak işaret alanını kullanır. 
Dış sesler ve efekt sesleri: İşitsel kanaldan aktarılan dış sesler ve efektlerin işaret dili çevirisinde iletilmesi kimi zaman metnin anlamlanması için önemlidir.

Kimi zaman da, bu seslerin iletimi çocuk alıcı için görsel gürültü haline gelir ve kafakarışıklığına neden olabilir.

Dolayısıyla, dış ses ve efektlerin bazı kısıtlar ve parametreler düşünülerek işaret dilinde yansıtılması önemlidir.

1) Dış ses ve/ya efekt hikâyenin bütünlüğü içinde merkezi bir anlam ifade ediyor

mu?

Çevirmenin bu soruya vereceği cevaba göre:

a. Dış ses veya efekti başka türlü ifade etmeye

b. Veya kısaca çevirmeye; karar verilir: Örneğin, bir sahnede çocuklar bir parktan geçerlerken çevrelerinde kuş cıvıltıları duyulmaktadır. Çevirmen bu 'sesi' aktarmak için (zaman ve uzam kısıtı yüzünden) diyalogları kısaltmak zorunda kalacaksa, bunu yapmaya yeltenmesi gerekmez. Ortamın park olduğu görselden anlaşılmakta, kuş cıvıltısı sesi ise verilen örnekteki hikâyede merkezi bir önem taşımamaktadır. Ancak, başka bir örnekte dış ses merkezi önemde olabilir. Bir çocuğun düştüğü ve acıyla bağırdığı duyuluyor. Çocuk karakterler bu sesi duyunca arkadaşlarına yardıma koşarlar. Bu örnekteki 'dış ses' önemlidir ve işaret dilinde yansıtılmalıdır. Dış ses görselde belirtilmiş ve anlaşılıyorsa, söz konusu kesitte bir sözcük yoğunluğu bulunuyor ya da zaman kısıtlaması var ise çevirmen bu sesi yansıtmamayı tercih edebilir.

2) Dış ses ve/ya efekt hikâyede ne kadar etkin bir öge?

Çevirmen görseli ve hikâye akışını dikkate alarak dış ses veya efekti yansıtıp yansıtmamayı seçebilir:

a. Örneğin, çocuk karakterler komiklik olsun diye 'telsizle konuşuyormuş gibi' telsiz sesi çıkarırlar. Karşı karşıya durmalarına rağmen ellerinde telsiz tutuyormuş gibi ellerini ağızlarına yakınlaştırıp birbirleriyle telsizle gibi yaparak 'şaka yaparlar/oyun oynarlar'. $\mathrm{Bu}$ örnekte olduğu gibi görselle de desteklenen bir dış ses (telsiz cızırtısı) vardır. Bu ögenin yansıtılmaması görselin anlamsızlaşmasına neden olacaktır.

b.Başka bir örnekte, çocuk karakterler bahçede bir deney yapmaktadırlar. Deneyde bir teraziyi dengede tutmaya çalışırlar. Terazi dengede durmayınca terazinin üstünde duran bir kova su terazinin önünde duran çocuğun üstüne dökülür ve çocuk ıslanır. Görselde kovanın devrildiği, suyun döküldüğü, çocuğun ıslandığı açıkça görülür. Bu gibi bir örnekte (su döküldü) gibi bir açıklama eklenmesi gereksiz olabilir.

3) Dış ses ve/ya efekt hikâyede hangi sıklıkla geçiyor?

Bir dış ses veya efekt hikâyede atmosferi sağlamak için veya kurgunun merkezi bir parçası olarak kullanılabilir.

Örneğin, bir robot ile bir sunucunun yer aldığı bir programda robot karakteri (elektronik tuş sesleri çıkartarak) konuşur. Sunucunun etkileşim içinde olduğu bir 
'karakterdir'. Robotu anlayan tek kişi sunucudur ve robota verdiği cevaplardan izleyenler robotun ne dediği konusunda çıkarımda bulunurlar.

Yukarıda verilen türde örneklerde bu 'anlaşılmayan sesin' veya 'dış sesin' yansıtılması önemlidir. Aksi takdirde karakterlerin etkileşimi anlaşılmayacaktır. Ancak bu bağlamda Robot'tan çıkan sesin yansıtılması yerine sunucu karakterinin robotla etkileşimde olduğunu yansıtacak şekilde konumlandırılması 'robottan bir iletişim/ses geldiği' gerçeğini yansıtabilir.

\section{Sadeleştirme}

$\mathrm{Bu}$ bölümde çocuk alıcıya yönelik işaret dili çevirisinde sadeleştirme yaklaşımına önekler verilmekte ve kılavuzun başka bölümlerinde değinilmeyen konulara değinilmektedir ancak, sadeleştirme yaklaşımı kılavuz boyunca açıklanan bölümlerde (bkz. nidalar, şarkılar vb.) de ayrıca anlatılmaktadır. Sadeleştirme yaklaşımı metni basite indirgemeyle karıştırılmamalıdır. Çocuk alıcıya iletilmesi gereken bilgide bir kaybın olmaması gerekmektedir. Nitekim çocuğun programa olan ilgisinde azalma riski olabilir. Konuşmada diyaloğun aynıyla aktarılmasını içeren sadeleştirmenin iki temel amacı vardır:

1) Çocuk alıcıya görsel olarak sunulan işitsel düzgünün (diyalogların) 'algılanabilir' olmasını sağlamak.

2) Türkçeleşmiş işaret kullanımından uzak durarak işaret dilinin kendi doğal yapısını korumak

Sadeleştirme yapıldığı durumlarda programın hitap ettiği yaş grubunun bilgisi (genel kültür, akademik birikim, dünya bilgisi vb. ve programın hitap ettiği yaş grubunun sözcük ve kavram dağarcığını geliştirme becerisi ve hızı göz önünde bulundurulmalıdır.

Sadeleştirme yaklaşımında birkaç farklı teknik kullanılabilir:

1) Kaynaktaki sözcük, kavram vb. sayısında azaltmaya gitmek

a. (Örnek: Görselde bir grup çocuk görünür.Bir yere gidilmesi düşünülmektedir.

'Sen, ben, Ayşe, Can, Hasan, hep birlikte gidelim' yerine 'Hep birlikte gidelim'

2) Kaynaktaki cümle yapısını değiştirmek

3) Kaynaktaki diyalogu aynıyla aktarmak yerine amaçlanan anlamı veya etkiyi yaratacak eşdeğeri ile karşılamak

4) Kaynaktaki iletiyi daha anlaşılır kılmak için 'yeniden dillendirerek/düzenleyerek ifade etmek'

5) Kaynak sözlü iletiyi Türk işaret dilinde ölçünlü bir dille ifade etmek.

Sadeleştirmede bilgi eksiltilmiyorsa, kafa karışıklığına neden olunmuyorsa, zaman ve uzam kısıtı varsa sadeleştirme yapılabilir. 
Çevirmen açısından sadeleştirmede dikkat edilecek bazı temel ilkeler aşağıda belirtilmektedir:

1) Çeviri yaparken kelime, cümle yapısını, parmak alfabesinin kullanım tercihi ve şeklini alıcı kitleyi düşünerek belirlemek

a. Örneğin: Sözcük eksiltme ile -ìi Huylu Şef Roka yerine Aş̧ı R kullanımı- çocuk alıcı için daha kısa ve anlaşılır bir metin oluşturmak.

b. Örneğin: Görselde açıkça belirtilen bir sessel unsurun çevrilmemesi -Şef Roka'da her bölümde bir yere uçakla giderler ve bu görselde bir geçişle anlatılır. Açıkça görülen uçağın sesinin çevrilmemesi seçilmiştir.

2) Sözlü dilde iletişimde bireyler birbirleriyle konuşurken cümle içinde birbirlerine isimleriyle hitap ederler ve isimleri tekrarlarlar. İşaret dilinin doğal akışında böyle bir iletişim geleneği yoktur. İsimle hitap etme ve iletişim kurulan kişinin isminin tekrarlanması, işaret diliyle iletişim geleneklerine uygun olmadığı için, ayrıca kimin kiminle iletişim kurduğunun açıkça belli olduğu durumlarda gereksiz isim tekrarına neden olduğu için kullanılmamıştır.

3) Merkezi önemde olmayan veya hikaye kurgusuna veya akışına katkıda bulunmayan ses efektlerinin çevrilmemesi ve metnin sadeleştirilmesi düşünülebilir.

4) Hikaye kurgusunda öğrenim amaçlı olmayan tekrarların çıkarılması ve daha sade bir çeviri metin oluşturulması düşünülebilir.

5) Görselin kullanılması ve gerektiğinde görsele işaret ederek (sözcük ve cümle eklemeden) anlamın iletilmesi ile metin sadeleştirilebilir.

6) Görüntü ile eşsüremliliği sağlamak için kimi durumlarda çevirmen sessel girdiyi birkaç saniye geriden takip eder. Böylece görseldeki bilgiden de yararlanarak çeviri yapabilir. Örneğin, önemli bir binanın anlatıldığı bir kurguda ilk önce binanın ismi söylenmekte sonra görselde bina gösterilmektedir. Çevirmen bina görselini de kullanarak çevirisine açıkık getirmek için birkaç saniye geriden çeviri yapar. Bu gibi durumlarda eşzamanlılığı sağlamak için sonraki birkaç cümlede sadeleştirme yapılabilecekse yapılması, söz konusu kesit tamamlanana kadar çevirmenin eşsüremliliği yakalamasını sağlayacaktır.

7) Görselden destek alındığı bazı durumlarda görsel ile verilen bilgi merkezi önemde değilse çevrilmemesi ve metnin sadeleştirilmesi düşünülebilir. Örneğin, görselde bir şehir hastanesinin önünden geçiliyor ve binanın üstünde Şehir Hastanesi yazıyor ama hikâyede merkezi önemde değil. Bu ögenin çevrilmesi bir anlam kaybına ya da hikâyeyi takip etmekte bir zorluğa neden olmuyorsa, ayrıca çevrilmesi de çeviriyi gereksiz uzatıyorsa çevrilmemesi düşünülebilir.

8) Anlamlanmaya katkıda bulunmayan sözcüklerin/ifadelerin çıkarılması: Anlamlanmaya katkıda bulunmayan sözcüklere nidalar (bkz nidaların çevirisiyle ilgili bölüm), tekrarlar veya görselde de açıkça seçilebilen betimlemeler örnek olabilir.

a. Çocuk programlarında sıkça tekrar yapılmakta bu uygulama sözlü anlatıda anlamayı 
pekiştirmektedir. Ancak, bu tekrarlar zaman zaman görsel kirliliğe ve kafa karışıklığına neden olabilir, çocuğun görsel hareketi takip etmesi zorlaşabilir. Bu nedenle sadeleştirme yapılması gerekebilir. Çevirmen, bu konuda zaman ve uzam kısıtını, söz konusu tekrarın metnin anlaşılması için merkezi önemde olup olmadığını, söz konusu tekrarın çocuğun anlamlandırmasını olumsuz etkileyip etkilemeyeceğini tartarak kararını vermelidir.

b. Sunucusu olan çocuk programlarında, program sunucuları, çocukların ilgisini programda tutmak ve her yapılanı açıklamak için genelde fazla sessiz ara koymadan, sözlü dilde kolay algılanabilen bir hızda (oldukça hızlı) konuşur.

Ancak, bu tür programlarda görselde yapılan işlemin izlenmesi için çocuk alıcıya zaman da vermek gerekir. Görseldeki şekli işaret dilinde aynı şekilde anlatmak mümkün olmayabilir. Gereksiz bir kirlilik söz konusu olur.

Dolayısıyla, sözü uzatmak, açıklamak, tekrarlamak veya izleyicinin ilgisini programda tutmak için iletilenlerin çevirmen tarafından değerlendirilmesi ve çocuğun anlaması ve takip edebilmesi göz önüne alınarak kimi yerde kısaltmaya gidilmesi gerekebilir.

9) Sesletimle anlamlanan diyalogların sadeleştirilmesi/açımlanması: Sözlü dil ile iletişime özgü bazı kalıplar ve/ya yapılar vardır.

Örnek:

Cafer: Ben de on dondurma yerim o Cafer ciddi bir ifadeyle söyler zaman!

A: "Ay sen de Cafer"..

-Cafer, saçmalama on

dondurma yenilmez

-Cafer çok komiksin, hiç on dondurma yenilir mi

-Cafer, on dondurma yemek doğru değil (hastalanırsın)

Bu replik, işitsel düzgüdeki sese ve vurguya erişimi olan biri için yukarıda verilen anlamlara gelebilir. Ancak, işitsel düzgüye erişemeyen biri için a) sen Cafersin; b) her ne yapılıyorsa/oluyorsa Cafer de bu gruba dahil/yapsın; c) Cafer'e bir şey söylenecekti ve cümle yarıda kaldı gibi anlamlara gelebilmektedir.

Çevirmen çevirisinde bu gibi durumlarda, kaynak metinde amaçlanan anlama sadık kalarak, kaynak metindeki duyguyu yansıtarak ve çeviri kısıtlarını dikkate alarak 'anlam odaklı' bir yaklaşım benimsemesi gerekir.

10) Yarım kalan cümleler: Konuşma sırasında bir kişinin belli nedenlerden dolayı (örneğin, başka birinin araya girmesi ve sözünü kesmesi, konuşurken kendini ifade edeceği sözcükleri bulamaması, dikkatinin dağılması vb.) karakterlerin cümleleri yarım kalabilir. 
Bu gibi durumlarda çevirmen "cümleyi tamamlama” tekniğini kullanır.

Örnek:
A: Bence sen yanlış yapıyorsun!
B: -ama

Eğer B karakteri neden yaptığına itiraz edildiğini anlamadıysa ve açıklanmasını istiyorsa

A: Bence sen yanlış yapıyorsun?

B: Ama nenden?

Projenin işaret dili çevirisi ayağında detaylı bir şekilde oluşturulan çevirmen kılavuzunun yanı sıra editör kılavuzu da geliştirilmiştir. Bu kılavuzda işaret dili çeviri sürecinde çevirmenin ürününü denetleyecek, gerekirse düzeltecek olan editör profili ve editörlük sürecinde kullanılacak ölçütler de belirtilmiştir. Söz konusu yaş grubuna yönelik olarak işaret dili ile çizgi film çevirilerinin kılavuzda belirtilen ilkeler, yaklaşımlar ve benzeri profesyonel standartlar gözetilerek yapıldığında alıcı kitleyi tatmin eden, kitlenin programlara erişimini sağlayan ürünler ortaya konabildiği tespitinde bulunulabilmektedir. Çalışmanın başında benimsenen 'çocuk alıcıya özgü' tasarımla' oluşturulan, kılavuzda belirtilen profildeki çevirmen ve editörün denetiminden geçen ürünlerin çocuk alıcılar tarafından benimsendiği ortaya konulabilmektedir.

\section{Sonuç}

Çalışmada ele alınan projenin amaç, süreç ve çıktıları Türkiye'de son yıllarda S/sağır ve işitme engelli gruplar arasında çocuk alıcılara yönelik olarak işaret dili çevirisi ile medya ürünlerine erişimde örnek teşkil edecek ürünleri, araştırma süreçlerini, çeviri sürecinde kalite standartlarının belirlenmesindeki her süreci, aktörleri, kıstasları, çevirmen seçimlerini ve konuları içeren detaylı kılavuzları ortaya koymaktadır. Sağır ve işitme engelli çocukların dahil olduğu projede çıktılar sağır çocukların alımlamasına göre şekillendirilmiş gerçek ve güvenilir verileri ortaya koyması açısından önemli ve yol göstericidir. Çalışma bir taraftan yetişkin gruba göre çok farklı bir duyarlılık ve beceri gerektiren çocuk alıcıya yapılan çeviri sürecinde teknik, strateji ve başa çıkma yollarını ortaya koyarken bu alanda uzmanlaşmak isteyen işaret dili çevirmenlerine ve editörlerine farkındalık ve yeni kazanımlar sağlaması açısından da bir kılavuz niteliğindedir. Konuşan duyan çocuklarda olduğu gibi S/sağır ve işitme engelli çocuğun sosyalleşmesi, kişiliğinin oluşması ve toplumsallaşmasında belirleyici olan kültürlenme, dil edinimi, bilişsel gelişimi açısından da bakıldığında çocukları bir yandan eğlendirmesi, bir yandan da kültürlenme sürecine katkısı açısından eğitici ve öğretici yanıyla da dikkat çekicidir.

$\mathrm{Bu}$ tür projelerin yapılması ve sonuçlarının ve bulgularının sistematik bir şekilde derlenmesi, daha sonrasında ise ürünler bazında yapılacak alımlama çalışmaları ile desteklenmesi ve böylece, uzmanların ve çevirmenlerin yanı sıra alıcılardan da 
dönüt ve girdi alınması çok merkezi önemdedir. Bu tür projeler ve çalışmalar bir tartışma platformunda son noktayı koyan çalışmalar değildir. Burada sözü edilen tüm ayrıntıların alıcılar üzerinden de test edilmesi ve buradan elde edilen verilerle sözü edilen türden kılavuzların nihai halini alması gerçek anlamda engelsiz erişimin sağlandığının kanıtı olacaktır. Bunun bir uzantısı ise farklı uygulayıcı grupların farklı kılavuzlar ortaya koyması ve bunları ortaya koyarken de yukarıdaki çalışmada olduğu gibi bunu araştırmaya ve bilimsel gerçeklere ve bulgulara dayandırması önemlidir. Bu farklı kılavuzlar bir bilgi birikimi oluşturacaktır. Bu toplam bilgi birikimi bir profesyonel alandaki mesleki paylaşım özelliği sergileyecek, bu mesleki paylaşımla ancak alımlama çalışmalarına doğru araştırmalara evrilebilecektir. Burada sözü edilen tüm bu süreçler emek yoğun ve kimi zaman da maddi olarak külfetli olabilen süreçlerdir. Akademi konuya sahip çıkarken diğer yandan da sorumluluğun bir kısmı bu ürünleri sunan medya platformlarına düşmektedir. Kendi hakkını savunamayacak kadar genç olan çocuklar veya bu çocukların uygulamalar konusunda derin bir bilinci olmadığı için eleştirmekte sıkıntı yaşayacak ebeveynlerinin şikayetlerinin olmaması sunulan ürünle hedefine ulaşıyor düşüncesi bu bağlamda pek de doğru bir yaklaşım olmayacaktır. Bu ürünlerin izlenme oranlarını takip etmek, tercih edilen ürün ve ürün türlerini saptamak, işaret dili çevirisi ile ilgili dönüt almak, alınan dönütleri derlemek ve gerektiği durumlarda kılavuzlara yansıtmak ve sürekli artan bir kalite döngüsü kurmak bu medya sağlayıcılarının asıl görevlerinden biridir. Zira bu bağlamda çocuk birey ve özellikle de dezavantajlı çocuk birey söz konusudur. Konuda her türlü hassasiyetin gösterilmesi esastır.

Projenin çıktılarından verim ve fayda sağlanması bu çıktıların uygulamaya konması ve süreklilik oluşturmasıyla doğruda ilişkilidir. Bu aşamada da medya sağlayıcılar, çocuk alıcılara yönelik programlarının izleme oranlarını takip ederek bu konuda süreklilik sağlamada önemli aktörlerdir. Bu çerçevede çıkan sonuç ve gözlemlerle akademi, Sağır editör ve çevirmenlerle işbirliğine gidilerek S/sağır ve işitme engelli çocukların ihtiyaç ve odak noktalarına, taleplerine yönelik yeni çalışmaları sistematik bir yapıda gerçekleşmesi amaçlanmaktadır.

Sonuç olarak, bir yandan S/sağır ve işitme engelli topluluklar bu ürünlere ve süreçlere sahip çıkmalı takibinde olmalıdırlar; bir yandan akademi ve uygulayıcılar her yerde yaşanan gelişmeleri ve bilgileri takip ederek güncelleme yapmaya hazır olmalıdırlar, diğer yandan da medya sağlayıcıları bu kadara hassas bir konuda en kaliteli ürüne erişebilmek için sürekli iyileştirme döngüsü kurmalıdırlar. Bu makalede sözü edilen proje ise bu gibi bir yaklaşım ve felsefenin ilk adımlarını içermektedir.

\section{Kaynakça}

AB Engellilik Stratejisi. (2010). https://www.turged.org.tr/Hukuk-EngelliMevzuati/Avrupa_Engellilik_Stratejisi_2010_2020.doc

Birleşmiş Milletler Çocuk Haklarına Dair Sözleşme: https://www.unicef.org/turkey/\%C3\%A7ocukhaklar\%C4\%B1na-dair-s\%C3\%B6zle\%C5\%9Fme 
Cómitre Narváez I., \& Ruiz, E. S. (2019). Sous-titrage créatif pour enfants sourds et malentendants: les contes au cinéma. Palimpsestes, 32, 203-222. https://doi.org/10.4000/palimpsestes.3635

Curio, S. (2020). Le métier d'interprète en langue des signes [Yayımlanmamış yüksek lisans tezi]. Aix-Marseille Üniversitesi.

Cuxac, C. (1992). Iconicité des langues des signes. Faits de langue-l'iconicité. PUF.

Dikyuva, H., Makaroğlu, B., \& Arık, E. (2015). Türk İşaret Dili dilbilgisi kitabı. T.C. Aile ve Sosyal Politikalar Bakanlığı Yayınları.

Gaucher, C., \& Vibert, S. (2010). Les sourds aux origines d'une identité plurielle. Peter Lang

Lorenzo Garcia, L., \& Pereira Rodriguez, A. (2011). Deaf children and their access to audiovisual texts: Educational failure and the helplessness of the subtitler. E. di Giavonni (Ed.), Diálogos intertextuales 5: Between text and receiver: Translation and accesibility. Entre texto y receptor: Traducción y accesibilidad içinde (ss. 185-202). Peter Lang .

Napier, J. (2015). Comparing signed and spoken language interpreting. H. Mikkelson, \& R. Jourdinais (Ed.), The Routledge Handbook of Interpreting içinde (ss. 129-143). Routledge.

Neves, J. (2008). Le sous-titrage pour sourds et malentendants. J. M. Lavour, \& A. Şerbane (Ed.), La Traduction Audiovisuelle içinde (ss. 43-54). De Boeck.

Okyayuz, A. Ş. (2019a). Görsel-işitsel çeviri ve engelsiz erişim. Siyasal Kitabevi.

Okyayuz, A. Ş. (2019b). Ayrıntılı altyazı çevirisi. Siyasal Kitabevi.

Oral, A. Z. (2016). Türk İşaret Dili çevirisi. Siyasal Kitabevi.

Pöchhacker, F. (1999). Getting organized, the evolution of community interpreting. Interpreting, $4(1), 125-140$.

RTÜK (2019a). Sağırların, İşitme ve Görme Engellilerin Medya Hizmetlerine Erişiminin iyileştirilmesi Çalıştayı. https://www.rtuk.gov.tr /assets/Galeri/Haberler/sagirlarinisitme-vegorme-engellilerin-gorsel-isitsel-medya-hizmetlerineerisiminin-iyilestirilmesicalistayi-sonuc-bildirisi.pdf

RTÜK. (2019b). Sağırların, işitme ve görme engellilerin yayın hizmetlerine erişiminin iyileştirilmesine ilişkin usul ve esaslar hakkında yönetmelik. Resmî Gazete (11 Ekim 2019). https://www.resmi gazete.gov.tr/eskiler/2019/10/20191011-15.htm.

Sancaktaroğlu Bozkurt, S., \& Okyayuz, A. Ş. (2020). Türkiye'de Sağır ve işitme engelli çocuklar için ayrıntılı altyazı çevirisi hakkında bir araştırma: Uygulamada sadeleştirme. Çeviribilim ve Uygulamaları Dergisi, (29), 139-160. http://10.37599/ceviri.824787

SEBEDER. http://sebeder.org/Projelerimiz-17.html

Wirth, F. (2008). Interprètes en langue des signes : autour de l'intervention de Marie-Thérèse L'Huillier à la Journée Mondiale de la Traduction, Traduire, 221, 33-38. https://doi.org/10.4000/traduire.344 